Universidade de Brasília

Departamento de Psicologia Clínica

Programa de Pós-graduação em Psicologia Clínica e Cultura

Ana Rosa de Sousa Amor

\title{
O TEMPO DA CONSTITUIÇÃO DO SUJEITO considerações sobre o tempo na psicanálise
}

Brasília - DF 
Universidade de Brasília

Departamento de Psicologia Clínica

Programa de Pós-graduação em Psicologia Clínica e Cultura

Ana Rosa de Sousa Amor

\section{O TEMPO DA CONSTITUIÇÃO DO SUJEITO considerações sobre o tempo na psicanálise}

Dissertação apresentada ao curso de Mestrado em Psicologia Clínica e Cultura do Departamento de Psicologia Clínica da Universidade de Brasília, como parte dos requisitos para obtenção do grau de Mestre, elaborada sob orientação da Professora Dra. Daniela Scheinkman Chatelard.

Brasília - DF 
Universidade de Brasília

Departamento de Psicologia Clínica

Programa de Pós-graduação em Psicologia Clínica e Cultura

Dissertação de mestrado, intitulada $O$ tempo da constituição do sujeito - considerações sobre o tempo na psicanálise, de autoria da aluna Ana Rosa de Sousa Amor, apresentada pelo Programa de Pós-graduação em Psicologia Clínica e Cultura do Departamento de Psicologia Clínica da Universidade de Brasília, aprovada pela banca examinadora.

Brasília, 07 de agosto de 2015.

Dra. Daniela Scheinkman Chatelard

Universidade de Brasília — Presidente

Dra. Nina Virginia de Araújo Leite

Universidade Estadual de Campinas — Membro Externo

Dra. Márcia Cristina Maesso

Universidade de Brasília - Membro Interno

Dra. Estela Ribeiro Versiani

Escola Superior de Ciências da Saúde do Distrito Federal - Membro Externo - Suplente 
Ao meu pai, Pedro, e à minha mãe, Neusa, que amorosamente me mostraram no estudo um caminho. 


\section{Agradecimentos}

À minha avó, Cora (in memoriam), e à minha avó Lélia (in memoriam), por despertarem em mim o gosto por escutar histórias e por transmitirem um sentimento de tempo nas saudades que me deixaram. Ao meu avô, Rosalvo (in memoriam), e ao meu avô, Pedro (in memoriam), que, mesmo postumamente, transmitiram valiosas lembranças e também deixaram saudades.

Aos familiares, pelo incentivo e pela paciência; em especial à minha irmã Débora, que acolheu por diversas vezes minhas chorumelas e meus devaneios.

À professora Daniela, pelo caminho aberto ao estudo psicanalítico e por sua receptividade, orientação, pontuação, transmissão e cuidado durante este trabalho.

Aos colegas do grupo de pesquisa em psicanálise na UnB, pelos apontamentos e pela interlocução.

À Vânia, por escutar minhas confusões e me ajudar a procurar direções.

Aos amigos e amigas, pelo apoio; em especial à Aline, pela leitura cuidadosa e pelas ricas discussões; à Tainá, pela leitura atenta, pelos belos apontamentos e pelos comentários valorosos; ao Felix, pela tranquilidade e pelas sugestões acuradas; à Juliana, pelo reconhecimento e pelas indagações; à Laís, pela confiança e pela disponibilidade de discutir diversos aspectos da teoria e da clínica psicanalítica; à Fabíola, pelo entusiasmo e pelos momentos de lucidez que me propiciou; à Dani, por ser atenciosa e sensível às minhas ideias; à Carol pelo incentivo frequente, que mesmo com a distância, sempre chegou até aqui; à Manu, pelas inúmeras trocas em psicanálise e fora dela; ao Tomás, por ser tão prestativo e me ajudar com os desafios do pensamento; à Michele pelas observações certeiras e por me auxiliar a formular questões; ao Filipe, por ser tão compreensivo e por acreditar no trabalho psicanalítico; à Amanda, pela calma e pela força cativante; e à Luísa pela atenção dada a mim e a este trabalho, pela revisão, pelas pontuações, pelas conversas e por também se dirigir ao mistério que é o tempo.

Aos alunos que me acompanharam no estágio docente, por dedicarem tempo, se engajarem nos debates e contribuírem muito para as minhas reflexões.

Aos pacientes, por confiarem suas histórias à minha escuta.

A todos aqueles (foi muita gente!) que se fizeram presentes de alguma maneira nestes dias dedicados ao mestrado, com alguma palavra ou algum gesto, me fazendo perceber o tempo. Peço desculpas por não incluir o nome de todos, a minha memória falha.

À Universidade de Brasília, pela oportunidade de frequentá-la.

À Capes, pelo apoio financeiro. 
Para não matar seu tempo, imaginou: vivê-lo enquanto ele ocorre, ao vivo; no instante finíssimo em que ocorre, em ponta de agulha e porém acessível; viver seu tempo: para o que ir viver num deserto literal ou de alpendres; em ermos, que não distraiam de viver a agulha de um só instante, plenamente. Plenamente: vivendo-o de dentro dele; habitá-lo, na agulha de cada instante, em cada agulha instante: e habitar nele tudo o que habitar cede ao habitante.

E de volta de ir habitar seu tempo: ele corre vazio, o tal tempo ao vivo; e como além de vazio, transparente, o instante a habitar passa invisível. Portanto: para não matá-lo, matá-lo; matar o tempo, enchendo-o de coisas; em vez do deserto, ir viver nas ruas onde o enchem e o matam as pessoas; pois como o tempo ocorre transparente e só ganha corpo e cor com seu miolo (o que não passou do que lhe passou), para habitá-lo: só no passado, morto.

(João Cabral de Melo Neto, Habitar o tempo)

é preciso tempo para fazer traço daquilo que falhou [défailli] em se revelar de saída.

(Jacques Lacan, Radiofonia) 


\section{Resumo}

O presente trabalho foi produzido com o intuito de explorar a dimensão temporal na constituição do sujeito, de acordo com o pensamento de Jacques Lacan e em referência a um retorno a Sigmund Freud. Foi privilegiado o artigo de Lacan "O tempo lógico e a asserção da certeza antecipada", de onde partiram algumas elaborações acerca da incidência do tempo no sujeito do inconsciente. Para explorar a concepção de tempo na psicanálise, foram utilizados também alguns artigos de Freud e outros artigos e seminários de Lacan. Dentre os principais conceitos e categorias que tratamos, articulando-os ao tempo e ao sujeito, estão: trauma; aparelho psíquico; processo primário e processo secundário; recalque; inconsciente; divisão; repetição; linguagem; alienação e separação; ato; pensamento; saber; verdade; e castração. A temporalidade abordada neste trabalho convoca noções de retroação, a posteriori (Nachträglichkeit), só-depois (après-coup), futuro anterior, origem, atraso, antecipação, intervalo, descontinuidade, escansão, suspensão, corte, urgência, pressa, isto é, noções que compõem o tempo lógico. O tempo, marcado por pausas e alternâncias, faz nascer o sujeito, modula o ato e possibilita desejar.

Palavras-chave: a posteriori, só-depois, tempo lógico, constituição, sujeito. 


\begin{abstract}
This dissertation aims at exploring the time dimension in the constitution of the subject, according to Jacques Lacan, in reference to Sigmund Freud. The main article to this study is "Logical time and the assertion of anticipated certainty", that brings some elaborations on time and the subject of the unconscious. We also refer to some articles written by Freud and some of Lacan's seminars to explore the conception of time in psychoanalysis. Amongst the main concepts and categories that we deal with, articulating them with the ideas of time and subject, are trauma; psychic apparatus; primary process and secondary process; repression; unconscious; division; repetition; language; alienation and separation; act; thinking; knowledge; truth; castration. The temporality we investigate in this study brings to attention the notions of retroacting, $a$ posteriori (Nachträglichkeit), après-coup, future perfect, origin, delay, anticipation, gap, discontinuity, scansion, suspension, cut, urgency, rush --- notions that are part of the logical time. Time, with its pauses and alternations, makes the subject possible, modulates the act and allows the desire.
\end{abstract}

Keywords: a posteriori, après-coup, logical time, constitution, subject. 


\section{$\underline{\text { Sumário }}$}

Introdução

p. 10

\section{Capítulo 1}

A temporalidade a partir de Freud

p. 15

1.1 Dinâmica temporal do aparelho psíquico

p. 15

1.2 Processo primário e processo secundário: sobre antes e depois ...... p. 21

1.3 Tempo do trauma …............................................................... p. 24

1.4 Divisão psíquica - um corte temporal ….................................. p. 28

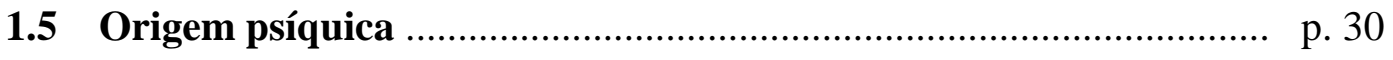

Capítulo 2

O tempo do sujeito - seguindo com Lacan …............................................ p. 36

2.1 Tempo do inconsciente - que passa e não passa ....................... p. 36

2.2 Repetição e sua relação com o tempo …................................... p. 40

2.3 Tempo lógico …................................................................... p.43

2.4 Tempo para constituir-se …................................................ p. 49

2.5 Tempo do sujeito …............................................................ p. 51

2.6 Tempo de dizer ............................................................. 54

\section{Capítulo 3}

Considerações sobre o que se faz com o tempo - em Freud e Lacan

3.1 Urgência do ato

3.2 O que se perde com o tempo p. 60

3.3 Tempo para não pensar p. 63 
3.4 Saber e verdade em relação ao tempo ..................................... p. 65

3.5 Origem de volta .......................................................... p. 70

Considerações finais ................................................................................ p. 77

Referências bibliográficas ..................................................................... p. 83 


\section{Introdução}

O presente trabalho foi produzido com o intuito de explorar a dimensão temporal na constituição do sujeito, de acordo com a teoria psicanalítica de Sigmund Freud e Jacques Lacan ${ }^{1}$. Procuraremos identificar as particularidades da compreensão acerca do tempo tanto em um quanto no outro autor, na tentativa de elucidar qual seria uma concepção de tempo própria da psicanálise, relativa ao sujeito do inconsciente e à condução do tratamento. Abordaremos a temporalidade por sua incidência em processos constitutivos, do aparelho psíquico em Freud e do sujeito de linguagem em Lacan.

As formulações de Freud e Lacan sobre a relevância do tempo para a explicação dos processos psíquicos aparecem frequentemente ao longo da teorização de ambos. Alguns apontamentos sobre o tempo na obra de Freud ajudam a compreender como Lacan toma a função do tempo na constituição do sujeito. Por isso, realizaremos inicialmente um decurso pela teoria freudiana para obtermos um melhor entendimento da temporalidade na constituição do sujeito na teoria lacaniana.

Freud não dedicou muitos artigos diretamente à dimensão temporal; porém, não deixou de destacar em vastas elaborações acerca da vida anímica a preponderância desta dimensão nos processos psíquicos e no tratamento pela fala. Ele apresenta uma concepção de tempo que rompe com a noção de linearidade e progresso. Para ele, os acontecimentos psíquicos só são passíveis de sentido a posteriori, nachträglich, no que isso implica de permanência e passagem do tempo.

Laplanche e Pontalis (2001) apontam no Vocabulário da psicanálise que os termos Nachträglichkeit (substantivo) e nachträglich (adjetivo e advérbio) são utilizados recorrentemente por Freud para expressar sua compreensão de temporalidade,

\footnotetext{
${ }^{1} \mathrm{O}$ título mais adequado para esta dissertação seria, na realidade, "O tempo na constituição do sujeito considerações sobre o tempo na psicanálise", conforme fora observado pela banca examinadora.
} 
no que se refere à causalidade psíquica. A noção de a posteriori faz parte do aparato conceitual freudiano e direciona as intervenções do psicanalista, de modo que, quando observada, reducionismos interpretativos podem ser evitados.

Nachträglichkeit é uma forma não linear de conceber o tempo que abala a ideia de causalidade do passado sobre o presente. O a posteriori de Freud não denota apenas uma descarga atrasada de tensão acumulada, mas um trabalho psíquico realizado nas formações sintomáticas por meio de operações como recalque, repetição, resistência, dentre outras. O sujeito modifica a posteriori o sentido dos acontecimentos passados, reorganiza, reconstrói, reinscreve o que aconteceu:

Não é o vivido em geral que é remodelado a posteriori, mas antes o que, no momento em que foi vivido, não pôde integrar-se plenamente num contexto significativo. O modelo dessa vivência é o acontecimento traumatizante. (Laplanche e Pontalis, 2001, p. 34)

Laplanche \& Pontalis (2001), Roudinesco \& Plon (1998) e Porge (1998), em dicionários de psicanálise, observam que Lacan conferiu um destaque especial a essa maneira de abordar a temporalidade. Ele irá salientar a retroação em Freud e introduzir a noção de après-coup (só-depois) na explicação de diversas operações psíquicas. Lacan, como aponta Porge, fará do só-depois um tempo de retroação de um significante sobre outro. Além de atribuir ao tempo um caráter fundamental na teoria psicanalítica freudiana, Lacan também irá propor outra concepção temporal, isto é, dará um passo em relação à Freud. Tal concepção, denominada tempo lógico, considera o surgimento do 
sujeito por meio de escanções e cortes que incidem no discurso enquanto este se desenrola.

Podemos adiantar que, dentre os artigos e seminários que selecionamos, "O tempo lógico e a asserção da certeza antecipada" de Lacan será privilegiado nesta dissertação, pois servirá de eixo para a investigação acerca do tempo na constituição do sujeito. Desse eixo, serão depreendidas algumas operações e categorias psicanalíticas, como a alienação, a separação, o ato, o saber e a verdade, a serem exploradas com o objetivo de vislumbrar algumas repercussões das especificidades da abordagem temporal na teoria lacaniana.

Porge aponta na definição de tempo lógico que essa relação entre lógica e tempo possivelmente foi proposta por Lacan numa tentativa estabelecer na estrutura do sujeito uma direção para a verdade. O tempo lógico não é uma lógica do tempo, mas a lógica de uma ação e uma deliberação que se sustenta por tempos:

Essa lógica dá à repetição de suas escansões um valor que não é o de situar o sujeito no tempo, mas de engendrar o sujeito da asserção pelos tempos dessas escanções, isolando pela mesma ação a função específica da pressa. (Porge, 1996, p.521)

Porge assinala ainda que Lacan traça por meio de escanções - instante de ver, tempo para compreender e momento de concluir - algumas coordenadas temporais no campo do Outro (uma alteridade radical para o sujeito). Desenvolveremos no presente trabalho as escansões que caracterizam o tempo lógico, devido a sua função de corte na linguagem e cujo efeito será a possibilidade de surgir um sujeito. 
Esta dissertação está dividida em três capítulos, mais esta breve introdução e algumas considerações finais. No primeiro capítulo, intitulado A temporalidade a partir de Freud, trataremos da concepção freudiana de tempo, Nachträglichkeit. Abordaremos a temporalidade atrelada aos processos psíquicos, fundamentando-nos em algumas funções e conceitos psicanalíticos, dentre os quais estão: o aparelho psíquico; o trauma; o processo primário e o processo secundário; a divisão psíquica; e o recalque. Os principais artigos de Freud que utilizaremos com esse propósito serão: "Projeto para uma psicologia científica”, "Estudos sobre a histeria", "Interpretação dos sonhos”, "A cisão do Eu no processo de defesa", "A negativa" e "O recalque”. Buscaremos, com este capítulo, estabelecer algumas condições para a compreensão da abordagem lacaniana de tempo e estrutura subjetiva, que será observada no capítulo seguinte.

No capítulo 2, intitulado $O$ tempo do sujeito - seguindo com Lacan, dedicar-nosemos a tratar da concepção lacaniana de tempo lógico, e sua implicação na constituição do sujeito de linguagem. Procuraremos elucidar a relevância do tempo a partir de algumas operações, categorias e conceitos psicanalíticos, tais como: o inconsciente; a divisão subjetiva; a repetição; a estrutura da linguagem; a alienação e a separação. Utilizaremos para esse fim os artigos "O tempo lógico e a asserção da certeza antecipada", com relevo, "O estádio do espelho como formador da função do eu", "Função e campo da fala e da linguagem em psicanálise" e "Radiofonia", bem como os seminários $O$ eu na teoria de Freud e na técnica psicanalítica, As psicoses e Os quatro conceitos fundamentais da psicanálise.

Por fim, no capítulo 3, intitulado Considerações sobre o que se faz com o tempo, exploraremos algumas repercussões da temporalidade inerente à constituição do sujeito no uso de alguns conceitos e categorias concernentes à psicanálise, quais sejam: o ato, o pensamento, a verdade, o saber e a castração. Com essa finalidade, utilizaremos 
principalmente os seminários $O$ ato psicanalítico, $O$ avesso da psicanálise e Mais, ainda de Lacan, bem como os artigos "Radiofonia", também de Lacan, "Sobre a transitoriedade", "Análise terminável e interminável", "A cabeça da Medusa" e “Construções em análise”, de Freud. Tentaremos, neste capítulo, encaminhar algumas considerações acerca da direção que o sujeito toma pelo tempo.

Lacan sugere que tenhamos como orientação uma trama lógica presente no discurso; ao propor uma noção de sujeito que se esvanece, recorre à lógica para torná-lo articulável. Escolhemos não introduzir aqui a leitura lacaniana acerca da lógica clássica e da lógica formal nem da topologia - presentes em alguns dos seminários por nós utilizados e cuja importância nós não ignoramos - por entendermos que esta abordagem daria outra direção à dissertação e extrapolaria nossos objetivos com o artigo do tempo lógico.

As análises que nos propomos a realizar dizem respeito a uma compreensão mais detalhada da constituição subjetiva depreendida do sofisma dos três prisioneiros presente no artigo de Lacan sobre o tempo lógico. Almejamos elucidar algumas consequências das declinações presentes neste sofisma que recaem sobre o sujeito de linguagem, especialmente no que concerne aos efeitos de significante, ao tempo de dizer e à clivagem entre a enunciação e o enunciado, que comparecem no tratamento psicanalítico. 


\section{Capítulo 1}

\section{A temporalidade a partir de Freud}

Teus olhos estarão sobre nós, infindáveis ó túneis do universo, ó caminhos serenos que passaremos sem agoras e sem ontens?

(Cecília Meireles, Solombra)

\subsection{Dinâmica temporal do aparelho psíquico}

O pensamento freudiano não se furtou à dinâmica temporal da vida mental; ao contrário, reivindicou atenção à pertinência do tempo para o funcionamento do aparelho psíquico, talvez conferindo ao inconsciente e à psicanálise uma temporalidade própria. No entanto, não há muitos artigos de Freud dedicados diretamente a essa dimensão da vida anímica. O tempo flui nos escritos de Freud e, de fato, comparece com alguma centralidade, apesar de não ser o eixo principal, em alguns artigos fundamentais. Selecionamos para este capítulo alguns artigos para tratar da incidência do tempo na formação do aparelho psíquico. Optamos por aqueles que contêm conceitos necessários à constituição psíquica e que apresentam em sua abordagem uma compreensão temporal. Buscaremos, de certa forma, fazer uma costura com o fio do tempo fornecido pela noção freudiana de a posteriori, nachträglich e Nachträglichkeit, ou seja, de um depois que retroage sobre o antes e de um antes que só se faz pelo depois. 
Dentre algumas funções psíquicas e alguns conceitos psicanalíticos de que escolhemos tratar, para a finalidade deste capítulo, estão: o aparelho psíquico; o trauma; o processo primário e o processo secundário; a divisão psíquica; e o recalque. Os principais artigos de Freud que iremos explorar com esse propósito serão: "Projeto para uma psicologia científica", "Estudos sobre a histeria”, "Interpretação dos sonhos”, "A cisão do Eu no processo de defesa", "A negativa" e "O recalque".

A lógica do a posteriori aparece nas elaborações freudianas sobre o funcionamento do aparelho psíquico desde os primeiros trabalhos psicanalíticos. Freud já oferece essa explicação temporal no "Projeto para uma psicologia científica" (1895) e nos "Estudos sobre a histeria" (1895). Os acontecimentos psíquicos só são passíveis de decifração a posteriori, o que implica permanência e passagem do tempo. Nachträglichkeit aponta para um abalo na representação linear de temporalidade e na ideia de causalidade do passado sobre o presente e sobre o futuro.

As elaborações iniciais de Freud acerca dos eventos psíquicos configuram sua teoria do trauma. Essas considerações demandam uma temporalidade específica, de forma que uma situação traumática só possa ser qualificada como tal posteriormente. Uma atenção voltada para o trauma marca as elaborações iniciais acerca dos eventos psíquicos e direciona as elaborações posteriores. Freud esbarra no traumatismo a cada passo que dá em direção a algum esclarecimento da vida mental; ele identifica um núcleo impenetrável de cunho traumático ao qual se remeterá a formação sintomática, a fantasia sexual, a realidade psíquica ou qualquer produção de sentido realizada pelo sujeito $^{2}$.

\footnotetext{
${ }^{2}$ A implicação de uma temporalidade na relação entre a fantasia e o sintoma é observada por Freud em "Uma criança é espancada" (1919) e "O problema econômico do masoquismo" (1924). Não exploraremos esta relação aqui por havermos privilegiarmos outros aspectos da constituição psíquica, tendo em vista a finalidade deste capítulo.
} 
O "Projeto para uma psicologia científica", como o título insinua, tem o intuito de fazer da psicologia uma ciência natural — psicologia científica e naturalista ${ }^{3}$ capaz de fundamentar a clínica baseada na palavra. A proposta freudiana para uma psicologia científica e naturalista, que precisa tomar a física como modelo, confere desde então uma relevância ao tempo. É necessário observar a incidência do tempo nos processos psíquicos, já que eles são compreendidos aqui conforme fenômenos físicos que obedecem a uma ordenação de movimento. O aparelho psíquico será dotado de energia que circulará por ele, de quantidades de movimento responsáveis pela realização de um circuito $^{4}$.

O aparato neurológico especificado no "Projeto" é composto por neurônios que são permanentemente influenciados pela excitação, destinados à função da memória, e por neurônios que são imutáveis, livres para receber excitações inéditas, destinados à percepção $^{5}$. O sistema nervoso tem então a propriedade de reter estímulos e também a de permanecer receptivo, isto é, de conservação e liberação. A memória age sobre o que poderá advir. Por isso, Freud recomenda que suspeitemos das sensações e da memória ${ }^{6}$. A memória exige um registro deixado pela experiência - o corpo fica marcado. O

\footnotetext{
${ }^{3}$ Gabbi Jr. (2003), em Notas a projeto de uma psicologia: as origens utilitaristas da psicanálise, discute como a epistemologia se insere na metapsicologia freudiana e aponta que a pretensão naturalista do "Projeto" denota a influência do empirismo no pensamento de Freud naquele momento. Essa influência caracteriza as elaborações freudianas presentes no texto e confere ao aparelho psíquico um funcionamento mecânico, que segue as leis da física. Com a física moderna, os fenômenos deixam de ser explicados por propriedades próprias da substância para serem explicados pelo movimento — que é exterior aos corpos, cabe salientar.

${ }^{4}$ Por aquilo que mais tarde Freud (1915) chamará de circuito pulsional em “As pulsões e seus destinos”.

${ }^{5}$ Freud os caracteriza como $\varphi$, sistema de neurônios da percepção, e $\psi$, sistema de neurônios da memória. Além desses sistemas de neurônios, há ainda o de neurônios $\omega$, que se destinam à sensação consciente conferida à percepção. Dessa forma, o movimento neuronal consiste em "modificações que passam através de $\varphi$, via $\psi$, até $\omega$, e aí, onde estão quase desprovidos de quantidades, geram sensações conscientes de qualidades" (Freud, 1895, p. 362).

${ }^{6}$ Essa recomendação diz respeito ao limite da rememoração e será feita ao longo de toda a teorização psicanalítica de Freud, conforme aparecerá ainda em "Estudos sobre histeria" (1895), "Lembranças encobridoras" (1899), "Interpretação dos sonhos" (1900), "Psicopatologia da vida cotidiana" (1901), "Repetir, recordar e elaborar" (1914), "O inconsciente" (1915), "O recalque" (1915), "Uma nota sobre o bloco mágico" (1925), "Construções em análise” (1937), dentre outros textos.
} 
tempo é o que irá conferir algum sentido aos registros, fazendo da memória uma construção que passa pela consciência no aparelho psíquico. A consciência das excitações é sempre mediada pela memória e a memória, como tal, o traço mnêmico, a marca no organismo, não chega ser consciente.

O sistema nervoso busca identidade entre recordação e percepção, mas para haver a identidade é preciso antes fazer a diferença. O sujeito só pode reconhecer um objeto presente como fonte de satisfação — quando ele coincide com a recordação de outro objeto, parecido, que trouxe satisfação - porque houvera antes ausência de satisfação durante alguma recordação, por estar ausente o objeto desiderativo ou ainda por estar presente um objeto hostil. Obtém-se, com isso, um problema mal resolvido, ou parcialmente resolvido. A identidade almejada jamais será total e resta ao sujeito encontrar algo parecido com aquilo que busca, algo que se pareça com aquilo que ele tem de referência em si mesmo. Com isso, será possível ao sujeito não ser, mas parecer: “por meio de seu semelhante, o homem aprende a se reconhecer" (Freud, 1895, p. 207).

Freud nota de maneira perspicaz que os dispositivos corporais têm limite de eficiência e falham quando um limite é ultrapassado. $\mathrm{O}$ aparelho psíquico admite a falha em seu funcionamento - falha expressa em fenômenos que beiram o patológico. $\mathrm{O}$ organismo se mobiliza perante um excesso de estimulação, um evento traumático inassimilável. O limite do organismo, sua incapacidade de tudo processar, é evidenciado também na impossibilidade de tudo conhecer. Os processos psíquicos podem prescindir da percepção da consciência; a consciência não nos fornece conhecimentos completos, não acessa os fenômenos físicos de forma imediata. A teoria psicológica, diz-nos Freud (1895): 
(...) tem de nos explicar tudo o que já conhecemos, da maneira mais enigmática, através de nossa "consciência"; e, uma vez que essa consciência nada sabe do que até agora vimos pressupondo - quantidades e neurônios também terá de nos explicar essa falta de conhecimento. (p. 360)

À medida que a complexidade do interior do organismo aumenta, o sistema nervoso recebe estímulos do próprio organismo, que também têm de ser descarregados. O aparelho psíquico complexifica-se, acompanhando a evolução do sistema nervoso. No entanto, o sistema nervoso está sujeito também a regressões, a voltar a ser o que era, sempre que acometido por estimulações excessivas, normalmente sentidas como dor. A dor pode ser compreendida como uma falha no sistema, que o impele para alguma fuga. A dor é suscitada por algo em falta, por alguma perda. Há, assim, um trabalho psíquico que é feito a partir da falha, de modo que a retroação já se apresente como um recurso importante para os mecanismos do psiquismo.

Algumas concepções freudianas acerca do aparelho psíquico foram profundamente modificadas, outras buriladas, mas grande parte delas — as primeiras intuições freudianas - persistiram ${ }^{7}$. O aparelho composto a partir de uma divisão fundamental é uma premissa valorosa mantida por Freud. Inicialmente, ele divide o aparelho em sistemas, da primeira tópica, como ficou conhecida essa primeira divisão ${ }^{8}$ : o primário, do inconsciente, e o secundário, da consciência. Depois, sem se desfazer

\footnotetext{
7 Em "Compêndios de psicanálise"/ "Esboços de psicanálise", Freud (1938/1940) retoma suas elaborações acerca do aparelho psíquico fazendo algumas complementações essenciais ao que fora exposto no "Projeto para uma psicologia científica" e na "Interpretação dos sonhos".

${ }^{8}$ Divisão presente na metapsicologia freudiana, encontrada em "Projeto para uma psicologia científica" (1895), "Interpretação dos sonhos" (1900), "O inconsciente" (1915), dentre outros artigos.
} 
dessa divisão, a ênfase recai sobre uma outra ${ }^{9}$, conhecida como segunda tópica, a das instâncias, que pode ser descrita sucintamente por esta divisão: o isso, pertencente ao inconsciente; o $e u$, formado a partir de uma parte do isso e de uma parte do mundo externo, pertencente ao inconsciente e à consciência; e o supereu, formado por uma parte do $e u$, pertencente ao inconsciente.

A primeira e a segunda tópica freudiana não se anulam nem se contradizem, mas acabam por se dialetizarem, evidenciando o que está no cerne da constituição do psiquismo: a divisão. Essa constatação será feita por Freud em diversos momentos do seu percurso teórico, comparecendo como condição para certos mecanismos e para formular alguns conceitos. Freud logo notou que se trata, em psicanálise, de trabalhar com limites, de tal forma que avançar implica reconhecê-los, torná-los evidentes e nem sempre superá-los. Por fim, Freud nota com mais perspicácia que a divisão recai sobre as instâncias. Ele passa a dizer de forma mais abrangente que existe uma cisão no eu, Ichspaltung.

Analisaremos adiante a dimensão temporal necessária à compreensão dos sistemas primários e secundários. Nachträglichkeit esclarece os processos psíquicos primários e secundários enquanto modos de funcionamento dos mecanismos psíquicos — que são possíveis apenas por meio de intervalos, pausas e escansões. A noção temporal de a posteriori, que implica na retroação de um funcionamento sobre outro, será essencial para situarmos, em seguida, a centralidade do trauma na constituição do aparelho psíquico e, logo depois, para analisarmos a divisão psíquica na qual o traumático se insere.

\footnotetext{
${ }^{9}$ Divisão que começa a ser delineada por Freud em "À guisa de introdução ao narcisismo" (1914) e "Luto e melancolia" (1917), mas que é estabelecida, principalmente, em "O Eu e o Id" (1923) e artigos subsequentes.
} 


\subsection{Processo primário e processo secundário: sobre antes e depois}

Freud distingue dois sistemas no aparelho psíquico, que se tornam mais complexos por uma diacronia: sistema psíquico primário e sistema psíquico secundário. O sistema psíquico secundário é desenvolvido por uma necessidade do organismo que habita o mundo, que lhe é exterior, pela necessidade da vida, ao passo que o sistema psíquico primário é o que já estava lá. Inicialmente, o infans é incapaz de discernir se o objeto de satisfação tem existência real ou não, se está presente ou se é apenas uma recordação - é necessário um critério vindo de outro lugar para diferenciar percepção e ideia, servindo-lhe de signo da realidade.

Por influência do mundo externo, assim, uma parte do psiquismo organiza as memórias e percepções obtidas com a experiência, de forma a poder separar os estímulos internos dos externos. Essa organização, feita a partir de uma camada limítrofe do psiquismo com o exterior, dotada de órgãos de captação dos estímulos e de proteção contra os estímulos, será transformada em eu, em uma referência de si mesmo. O eu não coincide com a totalidade das experiências vividas, mas se refere a uma parte delas, que são processadas dentro de um limite; o eu se forma por uma divisão entre interno e externo que marca a diferença entre eu e não-eu.

A existência de uma instância que serve de crivo para a realidade só é possível a partir de um segundo sistema, já que o aparelho psíquico falha se não considerar as exigências do ambiente externo. Segundo Freud, caso o organismo funcionasse sem realizar alguma distinção entre aquilo que é exterior e aquilo que não é, entre o que é apenas uma lembrança e o que é real, jamais atingiria satisfação com um objeto, pois iria sempre aluciná-lo. Os processos psíquicos primários, que regem o inconsciente, consistem então em trilhamentos que levam à alucinação, uma vez que visam satisfação 
imediata. Na "Interpretação dos sonhos", Freud (1900) propõe que um primeiro desejar se faça pelo investimento em uma alucinação da lembrança de uma experiência de satisfação. Desejar, aqui, consiste em uma corrente que parte do desprazer em direção ao prazer, de modo que o desejo é o que coloca o aparelho em movimento.

Dessa forma, o movimento desejante visa uma satisfação impossível, visto que a alucinação do objeto acaba se mostrando insuficiente para promover o prazer ligado à satisfação. É justamente por ser impossível obter o objeto de satisfação pela alucinação, porque esse modo de funcionamento primário falha, que há a necessidade de um segundo sistema no aparelho psíquico, um processo secundário que desvia o caminho da alucinação para o mundo externo e que torna possível chegar a uma percepção real do objeto que trará satisfação, ainda que parcialmente.

O processo primário esforça-se para estabelecer, através de descargas de excitação, uma identidade perceptiva, ou seja, uma identidade entre a percepção atual e a satisfação original. O processo secundário, por sua vez, abandona essa intenção e adota outra, a de estabelecer uma identidade de pensamento. O pensar é uma via indireta que vai da lembrança de uma satisfação, de uma representação que tem o desejo inconsciente como meta, até outra representação, idêntica, da mesma lembrança promovendo uma associação. O pensamento busca vias de ligação entre as representações; porém, as censuras presentes no sistema psíquico secundário, que viabiliza o pensamento por representações na consciência, provocam obstáculos que impedem a total obtenção da identidade buscada. O processo associativo substitui uma representação por outra, o pensamento só pode prosseguir com as associações sofrendo desvios e deixando lacunas.

O sistema secundário é um desvio de percurso do sistema primário, na busca de uma solução para atingir a satisfação. Ele reduz a quantidade de estimulação interna, 
isto é, inibe os excessos pulsionais, numa tentativa de retificar o sistema primário. $\mathrm{O}$ processo secundário restringe o afeto aflitivo ao mínimo necessário para que ele atue somente como sinal para evitar o desprazer na atividade do pensamento. No entanto, esse objetivo raramente é atingido por completo, pois o sistema psíquico secundário não se sobrepõe ao primário. Ao contrário, o sistema secundário surge a partir do primário e lhe atesta a existência.

Freud (1900) afirma que, na realidade, o processo psíquico primário é uma ficção teórica necessária, visto que é concebido como pertencente ao aparelho mental desde o início, através de uma dedução possibilitada pelos processos psíquicos secundários que surgem posteriormente com o desenvolvimento do organismo. $\mathrm{O}$ acesso ao sistema primário se dá pelo que é produzido depois, conferindo-lhe uma anterioridade que poderá ser inferida logicamente. Freud (1900) nota um hiato na eficácia funcional do aparelho mental, uma vez que nele está previsto a existência de falhas. As falhas fazem parte do funcionamento do aparelho, pertencem a sua estrutura e, por isso mesmo, não podem ser eliminadas.

Os pensamentos produzidos por uma atividade secundária acabam se sujeitando ao processo psíquico primário, é o que mostram os sonhos e os sintomas. Em consequência do aparecimento tardio dos processos psíquicos secundários, os impulsos desejosos anteriores permanecerão inconscientes, sem jamais tornarem-se passíveis de completa inibição ou compreensão. Restará ao sistema secundário direcionar os impulsos provenientes do inconsciente pelas vias mais convenientes, a fim de evitar desprazer. Esse arranjo no psiquismo evidência uma força exercida pelos desejos inconscientes sobre todas as tendências mentais posteriores.

As impressões e associações produzidas pelo processo psíquico primário são simultâneas (uma sincronia), não são realizadas distinções progressivas; já com a 
intervenção do processo secundário, os eventos podem ser recordados em sucessão (uma diacronia) e, com isso, ser situados em relação à realidade presente. A função da nachträglich freudiana na constituição do aparelho psíquico se evidencia com as definições dos sistemas e instâncias que o compõe, pois os mecanismos psíquicos não se formam de uma vez, nem se auto engendram. O sistema primário possibilita o aparecimento do secundário e o sistema secundário assegura a existência do primário.

\subsection{Tempo do trauma}

Freud desempenhou uma extensa investigação acerca da etiologia dos sintomas neuróticos. Ao realizar essa pesquisa, logo se deparou com o fato de que seus pacientes não podiam fornecer informações suficientes, uma vez que a causa de seus sintomas eram desconhecidas para eles:

\footnotetext{
Na grande maioria dos casos não é possível estabelecer o ponto de origem através da simples interrogação do paciente [...] porque ele é de fato incapaz de recordá-la e, muitas vezes, não tem nenhuma suspeita da conexão causal entre o evento desencadeador e o fenômeno patológico. (Freud e Breuer, 1985, p. 39)
}

O método para aproximar-se da causa ainda assim estava contido na fala, não na simples interrogação, mas na hipnose. Era necessário hipnotizar o paciente para provocar suas lembranças da época em que o sintoma surgiu pela primeira vez, já que 
essa não era uma resposta deliberada. O discurso sob hipnose não é o discurso da consciência: a hipnose revela outro discurso. Freud reconhece durante os tratamentos de seus pacientes que o discurso consciente não é suficiente.

Ele segue o rastro dos sintomas: para ele, são as primeiras impressões da infância que fazem surgir o sintoma, o qual, por sua vez, persiste durante os anos subsequentes. O sintoma é, portanto, o que vem no lugar de outra coisa, uma metáfora. A conexão entre um acontecimento infantil e um fenômeno patológico é mais uma relação simbólica do que causal. Há um acontecimento traumático na origem, factual ou fictício, cuja relevância está no fato de que não passará por completo e ressoará em um sentido retroativo. Freud (1895) chama a atenção para o que vem a ser um trauma psíquico: aquilo que "age como um corpo estranho que, muito depois de sua entrada, deve continuar a ser considerado como um agente que ainda está em ação” (p. 42). O traumatismo pode ser compreendido como uma exterioridade que se mantém na estrutura psíquica.

Uma experiência que evoque afetos aflitivos — angústia — pode incidir no psiquismo na forma de trauma, reconhecido pelo efeito traumático. $\mathrm{O}$ trauma evoca um tempo estranho: que passa e não passa; pois, mesmo com o lapso temporal determinante para a formação sintomática, ele persiste sem sofrer desgaste. Esse efeito traumático insistente leva Freud (1895) a afirmar que “Os histéricos sofrem principalmente de reminiscências" (p. 43).

Ele se impressiona com o fato de que experiências tão antigas possam continuar agindo intensamente e se dedica a investigar os motivos para a magnitude dessas experiências. Desconfia de motivos sexuais, mas isso não se explica facilmente. O impacto das experiências infantis mais primitivas reside no fato de que elas encontram um psiquismo em constituição; a própria constituição é consonante a essas experiências, 
é o enfrentamento do excesso de estimulação recebido precocemente por um organismo ainda sem recursos para processá-lo.

O aparelho psíquico descrito por Freud é, para ele, o resultado de um arranjo corporal proveniente de uma dependência infantil de longa duração, decorrente da condição de desamparo em que se encontra o filhote humano. O nascimento sempre prematuro do bebê humano lhe confere uma insuficiência de saída, uma impossibilidade que não será de todo superada e que marcará o corpo. Há um real intransponível na experiência original, sem captura possível, que restará ao longo de toda a estruturação do aparelho psíquico. Disso resulta o caráter traumático das primeiras experiências infantis e o impacto sobre o funcionamento do aparelho.

A ocorrência de fenômenos que remetem o sujeito ao trauma levará Freud (1920) a questionar, em "Além do princípio de prazer" ${ }^{10}$, o princípio que rege o aparelho psíquico, o princípio de prazer. A insistência dos efeitos traumáticos revelou a existência de um resto de energia que não entra na constituição psíquica e que, por isso, não se submete ao princípio de prazer. A quantidade de excitação presente na vida anímica que não está enlaçada gera uma sensação desagregadora, a qual diverge da sensação prazerosa proveniente das primeiras satisfações. Tal sensação não poderia ser explicada pelo princípio de realidade, pois não houve no início finalidade alguma de obter prazer.

O princípio de realidade não é responsável por todas as experiências de desprazer, apenas por aquelas que seriam de prazer e que se converteram em desprazer. O que havia sido qualificado por Freud como um princípio de realidade pode ser compreendido como uma modificação do princípio de prazer, não um novo princípio.

\footnotetext{
${ }^{10}$ Freud (1920), em “Além do princípio de prazer”, aborda a compulsão à repetição em situações que não propiciaram prazer, como a repetição de sonhos com eventos traumáticos e a brincadeira infantil na qual a criança repete seu próprio abandono, para apontar que o princípio de prazer rege a vida mental, mas não comanda todas as suas manifestações. Existem comportamentos cuja explicação escapa a esse princípio, está fora, além dele.
} 
Freud reconhece que nem todas as moções pulsionais percorrem toda a maturação do organismo e a formação do corpo pulsional, há sempre um resto de energia psíquica que resiste. Existe uma parcela pulsional impassível à unificação, que não participa de forma alguma da unidade da imagem egoica e que, por isso, permanece intolerável.

Freud divide então as moções pulsionais entre as que unem, ligam, progridem na constituição psíquica, e as que não se ligam, permanecem livres, desvinculadas de qualquer objetivo restaurador. A separação entre Eros e Thanatos, como ele denomina a pulsão que enlaça e a que fica livre, respectivamente, é proveniente da constatação de que existe um desprazer — uma sensação de fragmentação ou aniquilamento — que não deriva do prazer, que não tem o prazer como referência inicial para a ele se opor. Thanatos revela uma tendência que está além do princípio de prazer, ou seja, que é mais arcaica e independente deste princípio. A insuficiência do princípio de prazer indica um para-além, primitivo e fora de domínio — indica que há uma anterioridade que nos ultrapassa, a qual Freud creditou uma pulsão de morte.

O psiquismo não está completo, sua constituição não se totaliza, pois possui uma falta irremediável — oriunda do desamparo primordial — vivificada pelo traumatismo. Para Freud a falha que o aparelho psíquico porta é, na verdade, o que lhe dá origem. Veremos que, para Lacan, o sujeito nasce dividido, de modo que qualquer mecanismo psíquico tem sua função implicada nessa divisão subjetiva. A vivência humana do tempo possui relação direta com essa divisão fundamental, o tempo, que incide na estruturação psíquica por meio de intervalos, pausas, retornos e saltos, salienta essa divisão e nos permite reconhecê-la. 


\subsection{Divisão psíquica - um corte temporal}

Freud utiliza o termo Spaltung — cisão, divisão, clivagem, fenda — com maior expressividade em textos mais tardios, como "Compêndio de psicanálise" (1938) e "A cisão do Eu no processo de defesa" (1938). Como mencionado, porém, a noção de divisão psíquica esteve presente ao longo de todo o trabalho freudiano. Os sistemas e as instâncias mentais se formam a partir de um limiar, possuem um núcleo de divisão em função disso e portam características do que o originaram. Dessa forma, não há apreensão total e pura da realidade, pois ela adquire características do indivíduo, tornando-se fundamentalmente realidade psíquica. $\mathrm{O}$ crivo é contaminado, impuro.

Freud (1938) lembra-nos de que, nos estados mentais patológicos, o eu torna a se aproximar do isso, ao mesmo tempo em que suspende ou afrouxa sua relação com o mundo exterior. A condição para a irrupção de uma psicose, por exemplo, é que a realidade tenha se tornado insuportavelmente dolorosa ou que as pulsões tenham se intensificado de forma extraordinária. Alguns estados mentais patológicos, como o fetichismo, que também é um deles, expressam nitidamente a existência de uma cisão psíquica, da qual decorrem duas atitudes opostas, mas que coexistem lado a lado: uma que leva em conta a realidade e outra que, sob influência das pulsões, separa o eu da realidade.

A cisão do eu na psicose ou na perversão merece ser considerada mais de perto, uma vez que não só condiz com diversos sintomas como lança luz na estrutura do aparelho psíquico, tornando-o mais inteligível. A cisão pode de fato ser compreendida como uma tendência do aparelho, que comporta a falha, a falta, a Spaltung. O furo já previsto no aparelho psíquico freudiano dá indícios de uma divisão que direciona seu

funcionamento; tem-se, com isso, o fundamento para o sujeito dividido que habita o 
discurso do inconsciente. $\mathrm{O}$ eu tem duplo objetivo, tanto de cessar certas exigências pulsionais, como de cessar estimulações externas aversivas. Ele não logra completamente nenhuma das alternativas, fracassa no desligamento total, fica dividido: "não importa o que o Eu empreenda em seus esforços por defesa, se é recusar uma parte do mundo exterior real ou rechaçar uma exigência pulsional vinda do mundo interior, o resultado nunca é completo, sem resto [...]” (Freud, 1940 [1938], p. 171).

A Spaltung identificada por Freud é estrutural. Há uma fenda que nunca será curada, mas mantida com o passar do tempo. A síntese, tomada como função do eu, está sujeita a vastas perturbações e, na verdade, não chega a se realizar. $O$ eu é uma organização que não se completa, pois tem como núcleo essa divisão, nasce de uma fronteira e se forma em torno dela. A constatação de uma divisão psíquica estrutural remete ao projeto freudiano inicial, que não foi abandonado de vez, como pode parecer com o descarte posterior das funções anatômicas. Ao contrário, ele mantém alguns aspectos essenciais na caracterização que faz do aparelho psíquico:

Nossa hipótese de um aparelho psíquico com extensão espacial, convenientemente composto e desenvolvido pelas necessidades da vida — que apenas num ponto específico e sob determinadas condições dá origem aos fenômenos da consciência — nos colocou em posição de construir a Psicologia em bases semelhantes às de qualquer outra ciência, por exemplo, a Física.

(Freud, 1940 [1938], p. 149) 
Freud permanece com o intuito de se aproximar do suposto estado real das coisas, mas, aqui, reconhece não poder alcançar esse estado real em si mesmo, porque tudo o que deduzimos tem de ser traduzido novamente para a linguagem, da qual simplesmente não podemos nos libertar. Está aí o que é, para ele, a natureza e a limitação da psicanálise — uma psicanálise se faz por seu limite. A técnica psicanalítica consiste em proceder com lacunas dos fenômenos da consciência; ao propor um descentramento como nova perspectiva de busca, a consciência deixa de ser um critério primordial para uma compreensão estrutural da psique. Por essa via, o psicanalista intercala entre os processos conscientes processos que são em si e para si incognoscíveis e que, portanto, só podem ser inferidos. Tratam-se de processos incompreensíveis, mas que, ainda assim, pelo desconhecimento, são colocados à prova, dão mostras de sua existência.

A psicanálise se faz por uma sucessão de descobrimentos, que não são exatamente superação de limites, mas descobertas dos próprios limites. A estrutura psíquica é apreensível por aquilo que vela e desvela. O que é revelado só o é à custa de um recobrimento em outra parte, apontando para uma perda inevitável, para a existência de uma falta irreparável.

\subsection{Origem psíquica}

Freud (1925), em "A negativa", detém-se a aspectos da constituição do psiquismo, em que podemos mais uma vez observar o caráter fundante da cisão psíquica. A divisão se apresenta na tentativa de distinguir o interno do externo. O que se atribui à exterioridade ou à coisa (das Ding) na primeira etapa da constituição psíquica, 
em um primeiro juízo, é se ela é boa ou má. De acordo com a expressão mais antiga dos impulsos pulsionais, aquilo que é bom deve ser introduzido e aquilo que é mau deve ser expelido. Freud (1925) ilustra esse movimento incipiente da seguinte forma: "Isto eu quero colocar dentro de mim e isto eu quero pôr para fora” (p. 148).

O juízo, em um segundo momento da constituição, após alguma diferença estabelecida entre dentro e fora do organismo, entre o que lhe concerne e o que não lhe concerne, deverá conferir ou não existência real à coisa representada no psiquismo. Trata-se de saber se uma representação pode ser reencontrada na realidade pela percepção, ou seja, se há identidade perceptiva. Tem-se, mais uma vez, uma questão de dentro e fora: o que for somente imaginado e, portanto, não-real, será subjetivo, por estar presente somente no interior; ao passo que o que for real estará também presente no exterior. Essas distinções são antes uma divisão necessária para a constituição prosseguir - o psiquismo se estrutura ao redor de uma fenda.

As representações se originam de percepções, podendo ser reproduzidas na ausência destas. Freud adverte-nos de que o confronto com a realidade, bem como com um objeto de desejo, só ocorre quando e se os objetos que outrora já trouxeram satisfação tiverem sido perdidos. O sujeito procura assim não encontrar um objeto pela percepção, mas reencontrá-lo. Como vimos, a separação entre subjetivo e objetivo não existe desde o início, uma distinção entre ambos se dá pela diferença existente entre o objeto percebido e a reprodução dele na memória, cuja representação não é inteiramente fiel. Fica retido no psiquismo o registro de traços do objeto, nunca sua totalidade; o objeto é deformado pela subjetivação. A totalidade é barrada ao sujeito e ao objeto.

A polaridade existente entre incluir e expulsar corresponde à polaridade das pulsões: a afirmação, Bejahung, refere-se à unificação, a Eros; a negativa, Verneinung, sucede a expulsão e pertence a Thanatos, à pulsão de morte. Enquanto a afirmação une, 
a negativa, proveniente de uma exclusão (Ausstossung) anterior e necessária para que se possa afirmar o que quer que seja, separa. O "não" estabelece a diferença para que a identidade possa ser afirmada, para indicar com um "sim" que houve semelhança entre o que está dentro e o que está fora.

O que se evidencia na análise da estrutura psíquica é que seus mecanismos são acessíveis apenas quando partimos de seus efeitos e os elucidamos retroativamente. É o que, por fim, veremos acontecer com o recalque, Verdrängung - mecanismo psíquico que direciona lembranças e esquecimentos e que, por isso mesmo, apresenta estreita relação com o tempo. O recalque só é observável através de um tempo transcorrido, temos notícia dos seus efeitos e das condições necessárias para sua realização quando alguma coisa não funciona muito bem, por disrupturas que aparecem com o tempo. Ele deixa rastros, indícios do retorno do recalcado.

Freud (1915), no $\operatorname{artigo~}^{11}$ dedicado ao recalque, salienta que esse conceito só é possível com a divisão entre consciente e inconsciente, sendo ele próprio um mecanismo que contribui para a instauração e manutenção dessa divisão. O recalque é um mecanismo que visa evitar o desprazer e, para tanto, promove um deslocamento do afeto. A finalidade de evitar desprazer chega a algum êxito também pelo tempo.

Freud explica então o processo de recalque por uma decomposição temporal. O recalque original, ou originário, Urverdrängung, inferido pelos efeitos do que lhe é posterior, consiste em interditar ao representante da pulsão a entrada e a admissão na consciência, estabelecendo um ponto de fixação que pode ser compreendido como início. A segunda etapa do recalque, recalque secundário, que Freud observa em funcionamento nos neuróticos em tratamento psicanalítico, refere-se a representações

\footnotetext{
${ }^{11}$ Freud (1915) dedica o artigo "O recalque" à elucidação do recalque e suas etapas, mas esse mecanismo também é explorado por ele em outros textos fundamentais, como "A interpretação dos sonhos" (1900) e "O inconsciente" (1915).
} 
derivadas do representante recalcado original. $\mathrm{O}$ recalcado original exerce forte atração sobre tudo o que, de alguma forma, pode se conectar a ele.

O recalque não se proliferaria por meio de novas representações capazes de trazer alguma mudança efetiva nos comportamentos do indivíduo, a fim de afastá-lo de situações que não lhe fossem prazerosas; não lograria êxito algum, não se realizaria se não existisse algo já recalcado antes, pronto para acolher o que for repelido pela consciência em um momento posterior. A possibilidade de logro, entretanto, é também a deixa para o retorno do recalcado. Os desvios feitos pelas mais variadas ligações com o recalcado original permitem o trânsito entre consciente e inconsciente e possibilitam seu retorno através do que pode representá-lo.

Por meio de uma alternância, de um vaivém psíquico, volta-se para a origem, de onde se partiu. Volta-se para a partida, para a falha que enseja o trabalho psíquico. Com o retorno do recalcado, sinal de que houve recalque, mas que também houve fracasso, o sujeito se vê partido e se depara com o que o partiu, com sua divisão. Os deslocamentos permitem ao sujeito levar consigo traços da origem para, assim, distanciar-se dela. Os deslocamentos permitem distanciar-se da origem carregando-a. Não deixamos tudo para trás, carregamos conosco uma marca original, um sinal de onde viemos, um registro como "Made in Germany", para onde formos, seja como formos.

Há já na primeira formulação da teoria do trauma uma compreensão singular de temporalidade - a ênfase no a posteriori (Nachträglichkeit) - que será própria à psicanálise. O sintoma foi entendido por Freud como símbolo de uma causa precipitante. O fenômeno patológico do sintoma reaviva as lembranças recalcadas, uma vez que traços mnêmicos não se extinguem. As lembranças recalcadas, correspondentes a uma liberação sexual incontornável pelo psiquismo, só se tornam traumáticas por uma

\footnotetext{
${ }^{12}$ Alusão feita por Freud (1925) em "A negativa”, que reaparece em outros artigos, para se referir a um sinal de origem, a uma marca original.
} 
ação posterior. O trauma é a marca de um excesso que esteve presente no início, e que não deixará de estar presente no final.

O termo nachträglich, vastamente utilizado por Freud para caracterizar a dinâmica da vida mental, aparece com destaque especial na constituição do aparelho psíquico. Um momento posterior, um só-depois, é necessário para a dedução daquilo que vem antes na constituição. O passado faz-se retroativamente, liga-se ao futuro e passa no presente - passagem e permanência estão implicadas no tempo. A temporalidade da psicanálise, anunciada já nos trabalhos iniciais e enfatizada também nos trabalhos finais, revela-se enquanto temporalidade do inconsciente. Os processos do inconsciente são intemporais, conforme Freud (1915) os caracteriza, isto é, não se alteram com a passagem do tempo e não obedecem a uma linearidade. A lógica do $a$ posteriori permite, assim, apreender algo do funcionamento inconsciente.

Existe um discurso fora da consciência que aproximou Freud da etiologia traumática do sintoma, a técnica para tratá-lo consistiu inicialmente em retroceder pela fala a momentos pregressos. O discurso vindo de fora, que apresenta o inconsciente, indica a direção da cura. O tratamento, é o que Freud percebe rapidamente, deve ser feito por meio da palavra, para que o processo psíquico originalmente ocorrido possa receber expressão verbal, para que seja possível conferir ao trauma um lugar no simbólico, uma vez que ele advém com a linguagem, é pela linguagem que se diz 'trauma'. Ele vê na cura, na fala, uma saída no simbólico.

Freud logo identifica a necessidade de considerar os acontecimentos $a$ posteriori, nachträglich, pois as reminiscências se formam pelo tempo e o tratamento deve considerá-las. O tratamento é composto por voltas, exige tempo, assim como a constituição do aparelho psíquico. A relevância do tempo para o tratamento pela fala está prevista na técnica psicanalítica desde sua formulação inicial. A atenção ao 
discurso fora da consciência, decifrado por retroação, inaugura o tratamento psicanalítico e permanece fundamental para a psicanálise ao longo de seu desenvolvimento. 


\section{Capítulo 2}

O tempo do sujeito - seguindo com Lacan

E atrás da aldeia,

$[\ldots]$

um buraco

e no buraco, todo dia,

o mesmo ato:

o sol descia

lento e exato.

(Vladímir Maiakóvski, A extraordinária aventura vivida por Vladímir Maiakóvski no verão na datcha)

\subsection{Tempo do inconsciente - que passa e não passa}

Lacan, assim como Freud, ressalta a necessidade de se compreender a temporalidade no trabalho psicanalítico. O tempo, fundamental na constituição subjetiva, é determinante na análise. Lacan dedicou alguns de seus escritos e seminários à questão do tempo, colocando-a no cerne da discussão sobre o que seria o campo psicanalítico e sua ética. Trataremos, neste capítulo, de alguns artigos de Lacan que auxiliam a entender a temporalidade implicada na constituição do sujeito. Para tanto, procuraremos elucidar a relevância do tempo a partir de algumas operações, categorias e conceitos psicanalíticos: o inconsciente; a divisão subjetiva; a repetição; a estrutura da linguagem; a alienação e a separação.

Para os objetivos deste capítulo, privilegiaremos o artigo "O tempo lógico e a asserção da certeza antecipada", de Lacan, de onde partem muitas de suas elaborações acerca do tempo e da constituição do sujeito e onde ele anuncia a noção temporal que 
ficará conhecida como lacaniana: o tempo lógico. Exploraremos também os artigos "O estádio do espelho como formador da função do eu", "Função e campo da fala e da linguagem em psicanálise" e "Radiofonia", bem como os seminários O eu na teoria de Freud e na técnica psicanalítica, As psicoses e Os quatro conceitos fundamentais da psicanálise.

A descoberta do inconsciente se encadeia às observações freudianas acerca do trauma psíquico, àquilo que constitui o núcleo das formações sintomáticas. A marca do trauma ausente da memória, mas de alguma forma presente, denota para Freud a clivagem psíquica. $\mathrm{O}$ sujeito é originariamente marcado por uma divisão. O inconsciente, conforme observa Lacan no seminário Os quatro conceitos fundamentais da psicanálise (1964), apresenta-se por pulsação, como abertura e fechamento, uma fenda que é trazida à luz por um instante, mas que logo em seguida se esvanece. O inconsciente é apreendido em uma experiência de ruptura, entre percepção e consciência, em um lugar intemporal, ou seja, no entre: há outro tempo em outra cena.

Lacan (1964) explicita a divisão do sujeito através da surpreendente constatação do inconsciente:

Tropeço, desfalecimento, rachadura. Numa frase pronunciada, escrita, alguma coisa se estatela. Freud fica siderado por esses fenômenos, e é neles que vai procurar o inconsciente. Ali, alguma outra coisa quer se realizar algo que aparece como intencional, certamente, mas de uma estranha temporalidade. $\mathrm{O}$ que se produz nessa hiância, no sentido pleno do termo 'produzir-se', se apresenta como um achado. (p. 32) 
O inconsciente se manifesta como o que vacila num corte do sujeito, de onde ressurge um achado que Freud assimila ao desejo. A modulação temporal confere ao inconsciente um caráter de descoberta, no que ele tem de efeitos produzidos retroativamente. A descoberta do inconsciente fura a teoria do conhecimento, pois ela é proveniente de um deslocamento do centro do saber ou, mais precisamente, de um descentramento.

Lacan (1953/1966), em "Função e campo da fala e da linguagem", volta-se para as implicações do tempo na estrutura subjetiva concernente à psicanálise. Ele procura falar de temporalidade por meio da técnica, busca o tempo do sujeito no tempo da cura e vice-versa. Ele menciona a duração da análise, alertando para o problema, identificado por Freud ${ }^{13}$, de fixar um fim. O tempo se refere, portanto, ao fim. A duração de uma análise é, antes de seu fim, indefinida, imprevisível. Não há prazo certo para a verdade do sujeito. Não se sabe quanto durará uma análise porque não se sabe a verdade de antemão. O tempo confere à psicanálise seus limites, indica os confins de seu campo.

A duração da análise se apresenta para Lacan como uma questão relativa tanto ao tratamento que se faz ao longo de várias sessões, quanto o que se faz a cada sessão. A duração de cada uma das sessões diz respeito ao tempo de trabalho, que não possui um padrão fixado externamente. O inconsciente demanda tempo para se revelar; porém, ele será mais bem apreendido pelo sujeito quanto menos este justificar o que quer dizer. O tempo que se oferece na análise está a serviço do inconsciente.

O inconsciente, isso se mede? Qual o tempo necessário para que ele se revele? O tempo do inconsciente e, por conseguinte, o tempo da análise é aquele em que algo acontece. A análise deve durar o suficiente para que o paciente se realize no trabalho, de

\footnotetext{
${ }^{13}$ Em "História de uma neurose infantil” (1917) e “Análise terminável e interminável” (1937).
} 
modo que uma duração suficiente não equivale a uma precisão cronometrada: "o homem em sua autenticidade evoca a fala que dura" (Lacan, 1953/1966, p. 314). O tempo da análise pode ser compreendido como o tempo de dizer. Lacan não cede quanto ao valor que têm, para a análise, as sessões de duração não fixada.

O sujeito conta sua história no tempo — no tempo que ele tem para contá-la e no que ele tem para contar do tempo - sem precisar contar os minutos. Imbuída de uma dinâmica temporal, a narrativa que se desenrola é contada pela posição subjetiva no discurso:

O que se realiza em minha história não é o passado simples daquilo que foi, uma vez que ele já não é, nem tampouco o perfeito composto do que tem sido naquilo que sou, mas o futuro anterior do que terei sido para aquilo em que me estou transformando.

(Lacan, 1953/1966, p. 301)

O passado não está dado, se faz só-depois (après-coup); além disso, aquilo que parece passado pode não ter passado e permanecer presente. $\mathrm{O}$ sujeito se constitui na busca de sua verdade; entretanto, ao realizar sua história, é no o futuro que ele toca a verdade. $\mathrm{O}$ futuro anterior ${ }^{14}$ abre para o sujeito seu sentido, descortinando a direção de seu desejo e impulsionando-lhe o movimento.

\footnotetext{
${ }^{14} \mathrm{Na}$ língua portuguesa o futuro anterior corresponde ao tempo verbal futuro do presente composto. Perini (2010), em Gramática do português brasileiro, elucida que a ideia presente neste tempo verbal é justamente a de um futuro anterior, por se referir a um evento futuro temporalmente precedente a outro evento também futuro. O exemplo que escolhe para expressar este tempo é: "já terei terminado".
} 


\subsection{Repetição e sua relação com o tempo}

O efeito de sentido ocorre no só-depois, porém, existe um limite do que se pode remanejar num só-depois ${ }^{15}$. Esse limite está no que a história tem de acabado, de um passado revertido na repetição. Lacan evoca a repetição, consonante com a noção freudiana de pulsão de morte, para indicar o limite da função histórica: o limite é a morte, não simplesmente como o que daria cabo à vida, mas como dimensão indeterminada do sujeito. Esse limite "representa o passado em sua forma real" (Lacan, 1953/1966, p. 319). Ele adverte que a repetição não é propriamente um eterno retorno, mas um atual, um presente que não passa ${ }^{16}$. A repetição é, portanto, sempre presente. Ela tem caráter de primeiro encontro, pois não se encontra a mesma coisa, o que se encontra é a falha; o sujeito se encontra dividido.

A repetição surpreende, pega o sujeito desprevenido, pois está atrelada à experiência traumática. Freud (1918) anuncia que a ativação da cena primária ${ }^{17}$ — traumática - não é uma recordação e tem o mesmo efeito que teria uma experiência recente. Os efeitos dessa cena podem ser protelados, mas ela não perde em nada sua novidade. O trauma se repete. A insistência da repetição nos introduz numa temporalidade estranha à consciência. O recalcado se apresenta com insistência.

\footnotetext{
${ }^{15}$ Soler (2009-2010), em A repetição na experiência analítica, explora as declinações do passado feitas por Lacan, reunindo formas de conceber o passado, dentre as quais o remanejamento dos significantes produz ou não efeitos no só-depois. Soler salienta o limite do que se pode fazer com o passado, ou do que pode se tornar passado.

${ }^{16}$ Soler (2009-2010) elucida que o passado real é o que não pode ser modificado nem apagado, não é remanejado pelo àpres-coup. Na historicização do sujeito o presente se mistura ao passado para remanejálo, ao passo que na repetição o passado real permeia o presente, comparece na historicização em curso. O passado real é "aquilo do passado que, justamente, não passa, nunca passou e jamais passará.” (p.58)

17 A cena primária foi descrita por Freud (1917) em "História de uma neurose infantil", no caso conhecido como o do homem dos lobos. Trata-se de um coito ao qual a criança assistiu ou imaginou ter assistido muito precocemente. Freud chega ao caráter determinante da fantasia primordial para a formação de um sintoma por meio da construção da cena primária.
} 
As formulações de Freud e de Lacan acerca da repetição e dos limites da rememoração, em relação à insistência do trauma, também conferem à experiência uma temporalidade propriamente inconsciente. Há, assim, um automatismo, um impulso que tende sempre a se repetir. Como afirma Lacan $(1954,1964)$ nos seminários $O$ eu na teoria de Freud e na técnica da psicanálise e Os quatro conceitos fundamentais da psicanálise, é na repetição que o ser do homem encontra seu caminho, sendo que a repetição demanda o novo ${ }^{18}$. Disso depreende-se a particular atualidade do trauma, isto é, sempre novo e já aí.

A constatação da divisão no psiquismo indica que a consciência não apreende a si mesma. As lacunas da consciência, os lapsos, sinalizam a existência do inconsciente, deslocando a ordem do discurso através de um descentramento de si. "O inconsciente é a verdadeira realidade psíquica" (Freud, 1900, p. 584). Existe, assim, uma tensão entre atraso e antecipação que se suspende apenas com um ato; trata-se de uma experiência de descentramento, em que o sujeito se desvia de seu rumo por um viés específico situado nele mesmo que o impede de vir a se compreender. Os efeitos resultantes dessa experiência são de arrebatamento, rapto. Algo se fixa no momento do trauma e permanece ao longo da vida, um traço que permanece sempre o mesmo, compelido a expressar-se por uma repetição. O trauma implica ruptura, o princípio de prazer é posto fora de ação. As tendências além do princípio de prazer são mais primitivas do que ele e dele independentes. $\mathrm{O}$ esforço do psiquismo que se constitui em torno dessa ruptura será o de tentar vincular a energia livre, arcaica, que irrompera.

Tem-se, com isso, a repetição de um desapontamento, um encontro falho, uma vez que aquilo que se encontra é a falta de encontro, de acordo com o que Lacan (1964) propõe tomando como ponto de partida a estrutura subjetiva. Há um fosso permanente,

\footnotetext{
${ }^{18}$ Essa formulação lacaniana é uma referência à concepção de repetição de Kierkegaard (1843) em A repetição.
} 
introduzido por uma ausência, como expressa a enigmática atividade da criança que brinca de ir embora com o objeto repetidamente. Essa brincadeira, que tanto intriga Freud $^{19}$, consiste no desaparecimento do objeto, um carretel, enquanto se profere fort (vá) e no reaparecimento enquanto se profere $d a$ (ali).

A brincadeira completa implica desaparecimento e retorno. Entretanto, é comum a repetição da primeira ação, apenas, como um jogo em si mesmo — incansável — desprovido de prazer. $\mathrm{O}$ jogo do carretel é a resposta do sujeito à ausência da mãe, em torno da qual ele nada mais tem a fazer senão repeti-la: "é o ponto mesmo em que ela o deixou, o ponto que ela abandonou perto dele, que ele vigia” (Lacan, 1964, p. 66). O jogo do fort-da é uma repetição, repetição da saída da mãe. Resta à criança repetir seu abandono, contornando o ponto que denuncia um desamparo primordial, sua falta estrutural.

É a si mesmo que o sujeito encontra na falta de encontro; sua falta fundamental, a Spaltung, é o que está fadado a encontrar surpreendentemente sempre no mesmo lugar. A marca original do sujeito, seu traço, repete-se a cada encontro falho. A repetição já aparece como tal no trauma; portanto, não é de uma reprodução do trauma que se trata o fenômeno da repetição, mas do real da experiência traumática, vivificada a cada encontro com a falta. A falta na origem não termina, não passa, mas segue com o sujeito.

\footnotetext{
${ }^{19}$ Em "Além do princípio de prazer" (1920).
} 


\subsection{Tempo lógico}

O tempo apresenta-se, para Lacan, como uma instância lógica que engendra o sujeito. O sujeito do inconsciente é um efeito que só é atingido a partir da fundação de uma estrutura de linguagem que se configura em uma alternância temporal. "O tempo lógico e a asserção da certeza antecipada" é um artigo no qual Lacan (1945/1966) delineia a constituição do sujeito e a necessidade, intrínseca a esse processo, do tempo. Com esse intuito, ele apresenta um problema lógico, que se caracteriza como sofisma, sobre três prisioneiros.

Trata-se, no sofisma, de três prisioneiros que são escolhidos pelo diretor do presídio para ter a chance de ganhar a liberdade. Ganhará a liberdade quem conseguir resolver primeiro um problema lógico que envolve os três. O problema é colocado a eles: há cinco discos que só se diferem por sua cor — três discos brancos e dois discos pretos; sem dar a conhecer quais deles serão escolhidos, o diretor prende um disco nas costas de cada um dos prisioneiros, de modo que nenhum prisioneiro pode ver a cor de seu próprio disco, pode ver apenas a cor dos demais. Cada um poderá examinar seus companheiros, sem comunicar o resultado da inspeção, e o primeiro que puder deduzir sua própria cor é quem se beneficiará da liberdade. Para ter a liberdade, a conclusão do problema deverá ser fundamentada em motivos lógicos. Dadas as instruções e aceitas as condições, cada um dos três sujeitos é adornado com um disco branco, sem se utilizarem os pretos. Depois de se haverem considerado entre si, surge o motivo de concluir:

"Sou branco, e eis como sei disso. Dado que meus companheiros eram brancos, achei que, se eu fosse preto, 
cada um deles poderia ter inferido o seguinte: 'Se eu também fosse preto, o outro, devendo reconhecer imediatamente que era branco, teria saído na mesma hora, logo, não sou preto'. E os dois teriam saído juntos, convencidos de ser brancos. Se não estavam fazendo nada, é que eu era branco como eles. Ao que saí porta afora, para dar a conhecer minha conclusão." (Lacan, 1945/1966, p. 198)

Lacan mostra como o tempo incide num processo que se efetua por escansões, não por continuidade. No sofisma, cada prisioneiro precisa afirmar quem ele é para ganhar a liberdade. Não há um tempo determinado para a realização desse trabalho sobre si mesmo, mas há um limite, que é dado pelos outros prisioneiros incumbidos do mesmo trabalho subjetivo, uma vez que podem realizá-lo mais brevemente. O tempo é dado pelo outro, o sujeito que deseja ser livre está inicialmente em atraso, visto que quem solucionar o problema lógico primeiro é quem terá a liberdade. Ao discutir o sofisma, Lacan localiza o sujeito real (prisioneiro A) e os sujeitos refletidos (prisioneiro B e prisioneiro C). O prisioneiro A designa cada um dos sujeitos como pessoalmente na berlinda e se decide ou não a concluir sobre si. Essa situação se repete para cada prisioneiro, que inicia assim um movimento lógico. Uma vez que tenha se realizado um progresso lógico, a conclusão sobre si será inequívoca. Ocorre uma incursão lógica, como um imperativo. Esse progresso se dá sob a condição de escansões suspensivas, isto é, movimentos suspensos no raciocínio do sujeito ${ }^{20}$.

\footnotetext{
${ }^{20}$ Porge (1994), em Psicanálise e tempo: o tempo lógico de Lacan, assinala que são as objeções ao problema que o caracterizam como sofisma e que fazem a solução existir como tal após as paradas e partidas do sujeito. Os tempos do erro estão integrados ao raciocínio, são necessários ao progresso lógico, ou seja, o tempo das objeções é fundamental para a validade do raciocínio, não lhe é exterior.
} 
Lacan, ao tratar, nesse artigo, da constituição do sujeito - aquele que diz, e diz de si - aponta para a primazia do tempo. O que está em jogo no processo lógico é a prevalência da dimensão temporal, não espacial. O que mais importa na discussão do sofisma não é o que os sujeitos veem, mas o que eles descobrem positivamente por aquilo que não veem (os discos pretos). O tempo incide enquanto negatividade do espaço. O que o sujeito não vê se torna um sinal, porque ele transformou três combinações possíveis em três tempos de possibilidade; importa aqui o tempo de parada.

A primazia do tempo ${ }^{21}$ direciona a compreensão da constituição do sujeito ao campo do desejo, de modo que a noção espacial de continuidade — imaginária — se esmaece frente ao sujeito lógico, sujeito do inconsciente e da linguagem. O tempo é marcado pelos intervalos, pelas pausas, não pela continuidade. Cronometrar o tempo, contar-lhe os minutos, fazê-lo contínuo, é espacializá-lo, isto é, imaginarizá-lo. É na alternância e na oscilação que o sujeito encontra alguma saída, uma saída no simbólico.

No sofisma são observadas duas escansões suspensivas, necessárias para a verificação de dois lapsos e três verificações. Por isso, de acordo com Lacan, é essencial o exame dos tempos constitutivos do sofisma, tomados como modalidades temporais que também compõem a constituição do sujeito. São três momentos de evidência que revelam valores lógicos. A instância temporal se apresenta de modo diferente em cada um desses momentos, o que revela uma descontinuidade tonal do tempo. É possível captar na modulação do tempo o próximo movimento do sujeito em direção à asserção de si.

\footnotetext{
${ }^{21}$ Kojève (1947), em Introdução à leitura de Hegel, explicita que o ser do homem, por se alimentar de desejos nunca satisfeitos completamente, será devir e que a forma desse ser não será espaço, mas tempo. Tendo em vista que a formulação teórica de Lacan teve influências de Hegel e Kojève, pode-se destacar este alcance da dimensão temporal na teoria lacaniana, no artigo "O tempo lógico e a asserção da certeza antecipada" especialmente.
} 
O primeiro momento de evidência para o sujeito é assim constatado: "Estando diante de dois pretos sabe-se que se é branco"22. Há, nessa constatação, uma exclusão que está na base. Esse é o instante de olhar, o primeiro instante. O que é especificado nesse instante é uma subjetivação ainda impessoal e transitiva. O sujeito se apresenta em uma forma geral (expressa pelo pronome impessoal do "sabe-se que..."). Sendo o único capaz de assumir o atributo do preto, o sujeito logo formula a segunda evidência.

"Se eu fosse preto, os dois brancos que estou vendo não tardariam a se reconhecer como sendo brancos" ${ }^{23}$, essa é a segunda constatação. Há, dessa forma, um tempo para compreender, em que o sujeito detém, na inércia de seu semelhante, a chave de seu próprio problema. Ao se colocar na condição daquilo que não é (preto), o sujeito fará precipitar aquilo que é, através do que ele supõe que o outro seja; é de reconhecimento que se trata. A evidência alcançada tem que ser constatada no outro semelhante - em pura reciprocidade. Nesse tempo o sujeito é indefinido e recíproco, além de ser ainda transitivo. Esse tempo se configura enquanto uma demora; nas palavras de Lacan: "O tempo para compreender pode reduzir-se ao instante de olhar, mas esse olhar, em seu instante, pode incluir todo o tempo necessário para compreender" (Lacan, 1945, p. 205).

Após a compreensão, emerge uma formulação evidente: “Apresso-me a me afirmar como branco, para que esses brancos, assim considerados por mim, não me precedam, reconhecendo-se pelo que são" 24 . Eis a asserção de si, pela qual o sujeito conclui o movimento lógico. É chegado o momento de concluir o tempo para compreender, como uma bolha que estoura. Essa constatação se apresenta logicamente

\footnotetext{
${ }^{22}$ Dissolução do sofisma proposta por Lacan (1945/1998), p. 204.

${ }^{23}$ Ibidem, p. 205.

${ }^{24}$ Ibidem, p. 206.
} 
como a urgência do momento de concluir. Não é por uma contingência dramática, ou pela gravidade do que está em jogo, como lembra Lacan, mas pela urgência do movimento lógico que o sujeito precipita seu juízo e, já se pode adiantar, sua posição desejante.

No momento de concluir, o sujeito é efeito do ato; ao julgar que não é preto, se apressa em afirmar que é branco. A tensão do tempo para compreender, a demora, inverte-se na tendência ao ato ${ }^{25}$. O ato se antecipa à certeza. O sujeito conclui sobre si pela asserção que antecipa uma certeza. O sujeito, em sua asserção, atinge uma verdade que poderá ser colocada em dúvida, mas que ele não poderia verificar se não a atingisse primeiramente na certeza.

As moções suspensas — os tempos de parada e as viradas temporais — revelam então seu valor fundamental na asserção de si que se manifesta em ato. Além disso, é também no momento de concluir que o sujeito aparece em sua originalidade, uma vez que o juízo conclusivo só pode ser portado pelo sujeito que formulou a asserção sobre si. O sujeito da asserção isola-se pela cadência do tempo do outro, isola-se da relação de reciprocidade. $O$ sujeito passa a ser, então, pessoal e intransitivo. O sujeito propriamente dito, ou melhor, aquele que diz, é lógico e se afirma em ato.

O disco está fora do alcance do olhar, sua cor é definida por inferência, o que faz da solução do problema um paradoxo, mas única solução possível. Para atingir a solução lógica, é necessário passarmos por uma experiência de variação na posição subjetiva, não por uma investigação empírica. A inferência daquilo que se é foi obtida pela experiência de objetivar-se em uma certeza antecipada. O sujeito se lança no futuro anterior com a precipitação de sua certeza. A liberdade, obtida com a solução do problema, será alcançada somente por meio da dedução do que se é pelo que não se é,

\footnotetext{
${ }^{25}$ Lacan (1967-1968) desenvolverá melhor essa concepção de ato no seminário $O$ ato psicanalítico, que abordaremos mais detalhadamente no próximo capítulo.
} 
sem que o sujeito se certifique de que está correto ou não. O acesso ao ser será pelo nãoser. A certeza antecipada, que infere o ser, aponta para a experiência no real do que houve de traumático na origem.

A solução para a liberdade será a conjugação do real com o simbólico na função do tempo. Essa conjugação não é sem o imaginário, já que existe um campo de visão; porém, é pelo olhar atravessado pela dimensão simbólica e pelo tempo transcorrido que se conclui na direção de uma liberdade. A função simbólica suporta o olhar em virtude da falta existente na imagem.

A dimensão da experiência atingida com o problema lógico destinado aos três prisioneiros não deixa de caracterizá-lo como um sofisma, um simulacro da verdade, por não haver a possibilidade de comprovação empírica na resolução. O sofisma é, ainda assim, uma maneira de falar da verdade. Não por acaso, Lacan escolheu um sofisma para servir de apoio às suas elaborações acerca da constituição do sujeito, uma vez que, em psicanálise, a verdade nunca é toda, mas pode ser obtida enquanto meiaverdade, partida, assim como o sujeito, de modo que atingi-la é possível somente por desvios, erros e falhas que funcionam como atalhos.

O sofisma tem valor de ficção ${ }^{26}$, assim como a fantasia do sujeito, de forma que a verdade poderá ser alcançada por meio de uma narrativa. A verdade da ficção aparece com uma volta discursiva. O discurso sofístico produz um efeito de alteração da realidade ${ }^{27}$, mais do que um efeito retórico. A sofística profere que "o discurso faz ser, e é por isso que seu sentido só pode ser apreendido a posteriori, em vista do mundo que ele produziu." (Cassin, 2005, p. 63) Com um sofisma, tal qual o dos três prisioneiros

\footnotetext{
${ }^{26}$ Cassin (2005), em $O$ efeito sofístico, indica que, ao longo da tradição do pensamento ocidental, a sofística esteve situada mais próxima da retórica e da ficção do que da filosofia, devido à sua maneira de estabelecer a verdade. Os sofistas consideravam as coisas efetivas, a realidade do mundo sensível e vivo, o movimento e a subjetividade; já os filósofos visavam a realidade absoluta de cada coisa, sem a mediação humana.

${ }^{27}$ A relação que se instaura entre o discurso sofístico e a realidade é delineada por Cassin (2005): "não é o discurso que comemora o de fora, é o de fora que se torna revelador do discurso" (p. 62).
} 
que nos apresentou o tempo lógico, depreendemos que o discurso faz ser e que o ser é um efeito do dizer. É necessário, dessa maneira, tempo para se fazer ser, para liberar o ser no dizer. A liberdade, nessa via, pode ser concebida, então, como liberdade de dizer, visto que, em psicanálise, não se trata de dizer tudo, mas de dizer livremente.

\subsection{Tempo para constituir-se}

O movimento lógico-temporal proposto por Lacan anuncia uma gênese lógica, por decantação do tempo, que coincidiria com o nascimento do psiquismo. Sobrevém uma gênese lógica, não exatamente ontológica. Lacan (1949/1966), em “O estádio do espelho como formador da função do eu", indica que o bebê sustenta sua postura diante do espelho, superando a precariedade dos movimentos, através de um apoio externo, para fixar a imagem no que ela tem de instantânea. $\mathrm{O}$ bebê humano reconhece como tal sua imagem no espelho, manifestando uma assunção jubilatória. O sujeito antecipa em uma miragem a sua maturação. A forma total do corpo só lhe é dada numa exterioridade. O estádio do espelho explicita que aquilo que existe no homem de despedaçado, de desvinculado, é o que estabelece sua relação com as percepções no plano de uma tensão original.

O narcisismo, momento constitutivo que Lacan retoma de Freud ${ }^{28}$, inserindo algumas modificações, pode ser compreendido como um processo que comporta uma alienação vital. O homem só percebe a unidade da imagem de seu corpo externamente e de maneira antecipada. A imagem que se obtém do corpo próprio é o princípio de toda unidade percebida nos objetos; essa unidade, porém, escapa a todo instante.

\footnotetext{
${ }^{28}$ Em "À guisa de introdução ao narcisismo" (1914).
} 
Após alienar-se à imagem será preciso separar-se dela, pois a percepção parte de uma condição de discordância fundamental, não adaptação essencial. Como já fora notado por Freud, a forma pela qual o bebê reage inicialmente ao mundo não será de todo modificada: os processos psíquicos primários podem ser desviados ou adiados, mas não serão desfeitos. Conforme vimos anteriormente, existe uma tensão entre os processos primários, preponderantes no psiquismo, mas incapazes de levar à satisfação com o objeto da realidade, e os processos secundários, sujeitos à interferência dos processos primários e do mundo externo.

A relação do sujeito com o objeto exprime uma temporalidade essencial para o

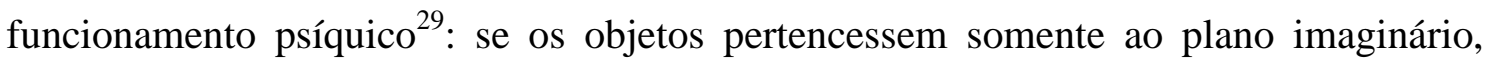
numa relação puramente narcísica com o sujeito, eles apareceriam instantaneamente e logo desapareceriam. Para que o objeto tenha alguma duração, tenha certa permanência, é preciso uma palavra que o nomeie, alguma articulação simbólica. Devido ao inacabamento inaugural, a experiência do sujeito é sempre relacionada ao corpo despedaçado, de forma que a emergência do sujeito do inconsciente é correlativa à desintegração da imagem de si. Esse processo comporta um resto de despedaçamento que não se objetifica; a unidade já é perdida ou nunca foi tida.

A mediação imaginária entre eu e objeto é sempre problemática, nunca se encontra efetivada. Caso o objeto percebido tenha sua própria unidade, o homem percebe a si mesmo como desejo, desejo insatisfeito. No entanto, se o homem apreende sua unidade, é o mundo que, para ele, se decompõe, perde o sentido e se apresenta sob um aspecto discordante. Essa oscilação imaginária aponta para um destino de alienação à imagem, que só pode ser interrompido por meio de uma intervenção simbólica. Somos inseridos num sistema simbólico que funciona ao mesmo tempo como condição de

\footnotetext{
${ }^{29}$ A mediação temporal na relação entre sujeito e objeto foi indicada por Lacan em diversos seminários, seguiremos o O eu na teoria de Freud e na técnica psicanalítica (1954-1955) para a finalidade deste capítulo.
} 
saída da alienação e sujeição a uma lei. A linguagem, como fundamento do sistema simbólico, é um terceiro regulador na relação dual imaginária.

Para Lacan, o eu, enquanto imagem, é um objeto privilegiado dentre os demais. A imagem na qual a criança se reconhece torna-se referência tanto para seu corpo em uma miragem de unidade, isto é, seu eu, como se torna também a matriz simbólica em que o sujeito se precipita. Com a função simbólica, ele sai da captura narcísica para se situar alhures. O estádio do espelho demarca a função de alienação e desconhecimento do eu e a hipótese de um sujeito que surge no intervalo entre um significante e outro, como efeito de linguagem, de modo que não há correspondência entre eu e sujeito. Entre o sujeito do inconsciente e a organização do eu há dissimetria.

\subsection{Tempo do sujeito}

O sujeito poderá ser definido a partir da relação estabelecida com o objeto. O objeto é instituído ao sair da dinâmica inicial de indiferenciação entre eu e não-eu pela interferência da linguagem, cuja função é a de um terceiro na relação entre sujeito e objeto. A função do terceiro está atrelada ao Outro e esse grande Outro, é importante situá-lo, é alteridade radical, na medida em que ele não é conhecido, mas reconhecido.

O Outro, como define Lacan (1955) no seminário As psicoses, é de natureza simbólica. O sujeito, quando fala, dirige-se para além do que se vê, dirige-se ao Outro. O Outro não é o reflexo visto, não é o semelhante, mas é o lugar do significante. No Outro, atam-se o reconhecimento de desejo e o desejo de reconhecimento. Esse Outro, simbólico, traduz a relação do sujeito com o significante e detém o enigma do desejo “O que queres?” (“Che voi?”). O sujeito, porém, converte esta questão em demanda - 
“Que queres de mim?” (“Que me veut-Il?”) ${ }^{30}$. Com isso, ele fica envolvido no tempo do Outro.

O que se constitui como imagem ou como função simbólica não estava aí desde o início. Como vimos, o "antes" se faz na constituição e só-depois dela, a linguagem inclui o trauma na estrutura. O estádio do espelho fundamenta as operações de alienação e separação, formalizadas por Lacan (1964) no seminário Os quatro conceitos fundamentais da psicanálise, presentes na constituição do sujeito, que emerge com o advento da fala.

A estrutura do sujeito é produzida, em um primeiro tempo, por sua alienação à linguagem. A alienação é, portanto, uma operação de identificação ao significante do Outro: o sujeito é marcado por um traço — a introdução primária de um significante, anterior ao próprio sujeito - para ser inscrito no campo do Outro e depois poder se identificar com outros significantes. O Outro marca no sujeito uma borda, inscreve-o no mundo da linguagem. Inicia-se uma troca de objetos variáveis, substitutos do objeto perdido. O Outro é o lugar em que se situa a cadeia de significantes que comanda o que vai poder presentificar-se do sujeito. O significante está primeiro no campo do Outro.

No entanto, o sujeito, em sua singularidade, não é todo determinado pelo significante do Outro. Para além da alienação, o sujeito inclui na sua constituição o que não se sujeita ao Outro. Na operação da separação, o sujeito se destaca do Outro. Tratase do momento de se separar da determinação do Outro. O sujeito se constitui subtraindo-se, tornando o Outro incompleto. Uma falta é encontrada no Outro, no discurso, e retroage sobre a própria falta do sujeito. A separação do Outro retrocede sobre a falta, que é justamente o que permite ao sujeito aceder a si mesmo.

\footnotetext{
${ }^{30}$ Jacques Lacan, Seminário 10 - A angústia (1962-1963).
} 
O sujeito é conduzido, pela dialética de sua constituição, da alienação à separação. A dialética dos objetos do desejo faz a junção do desejo do sujeito com o desejo do Outro. O enigma do desejo não é respondido diretamente, uma falta engendrada por um tempo precedente serve para responder à falta suscitada pelo tempo seguinte. É no limite das identificações, no que o desejo do Outro é desconhecido, no ponto de falta, que se constitui o desejo do sujeito. Tal falta é estrutural e propulsora de sua divisão.

Enquanto estiver preso ao tempo do Outro, capturado em uma continuidade, o sujeito não pode emergir, pois ele será justamente o que advém do intervalo. Retomando os tempos constitutivos do sofisma trabalhado por Lacan, é possível identificar um tempo de alienação, necessário para que o sujeito advenha. O tempo para a compreensão detém essa alienação necessária, para só-depois advir o sujeito. O que está em jogo nesse processo é a relação do sujeito com seu desejo, mas isso não se estabelece de uma vez, se faz com o tempo. Se o instante de olhar introduz o sujeito em uma situação na qual ele ainda não é, mas deverá ser o sujeito da enunciação, o tempo para compreender coloca-o na condição de outro, ele é seu eu-especular. Tudo o que sabe sobre si é o que apreende do outro, seu semelhante. Esse tempo de compreensão revela o outro e o objeto, é o que se atinge com o conhecimento, com a especulação exaustiva a que o sujeito se entrega.

A compreensão não é suficiente para aceder a si, pois não se trata aqui de conhecer a si mesmo: "O homem absorvido pelo objeto que ele contempla só pode voltar a si por um desejo" (Kojève, 1947, p. 11). Ao se separar do Outro, o sujeito encontra no desejo a saída para a sua condição de alienação. No entanto, só tendo se alienado ao desejo do Outro para se defrontar com o próprio desejo. Foi necessário 
desejar o desejo do outro, "desejar que o valor que eu sou ou que represento seja o valor desejado por esse outro" (Kojève, 1947, p. 14).

O sujeito, aquele que deseja, se constitui em torno de um centro que é o outro, o primeiro acesso que ele tem ao objeto é enquanto objeto do outro. Não há outro desvio para que o sujeito descubra o que lhe falta como objeto de seu desejo. A direção da asserção no momento de concluir sobre si é o desejo do sujeito da enunciação, daquele que diz. Uma direção para o desejo se delineia com a constituição subjetiva, e não é sem o trauma psíquico — indelével — pois desejar implica realizar voltas, desvios, escansões. O sujeito, passando pelo momento presente, veicula passado e futuro, sem sobrepor um ao outro; é assim conduzido por seu desejo a um tempo que lhe permite parar e prosseguir para seguir se revirando e se transformando.

\subsection{Tempo de dizer}

Lacan (1970) evoca o tempo para explicar a função da fala no tratamento psicanalítico. Em "Radiofonia", ele oferece algumas elaborações sobre o dizer na psicanálise, ressaltando o efeito obtido pela fala, que não é de comunicação, mas de deslocamento do discurso. As formações do inconsciente levam o sujeito a dizer através da palavra que não the vem, que lhe escapa, que lhe falta, é o que ocorre, por exemplo, no ato-falho. Os tropeços na linguagem revelam que o tempo não corre assim tão continuamente. As interrupções da narrativa diacrônica, por interferências inesperadas da linguagem habitada pelo sujeito, alteram o curso do que vinha sendo dito e indica que o encadeamento diacrônico está submetido a uma estrutura sincrônica da linguagem que concerne ao sujeito falante. 
O posicionamento do sujeito no discurso, sua forma de construir um mundo, como vimos com o sofisma dos três prisioneiros, varia de acordo com as alternâncias temporais, com as paradas e escanções. Para Lacan (1970), "Seguir a estrutura é certificar-se do efeito da linguagem” (p. 405). A estrutura faz traço de um projeto por vir: "só tendo ali ser de fato, por ser dito de algum lugar" (p. 406). A linguagem confere ao sujeito um lugar para a origem e uma veiculação para o ser. O ser atrelado à estrutura ganha corpo, o simbólico toma corpo. O corpo de linguagem portará uma marca originária, marca do ser, como o "Made in Germany" mencionado por Freud.

A introdução do significante no corpo habitado pela fala não deve ser tomada como uma coisa, pois ela se refere a uma falha estrutural. $\mathrm{O}$ ser nasce da falha que o ente produz no dizer, sendo o tempo uma condição para que isso se dê: “é preciso tempo para fazer traço daquilo que falhou em se revelar de saída" (Lacan, 1970, p.427). Freud já havia identificado a função do tempo no tratamento psicanalítico em virtude mesmo da preponderância da fala, pois o psicanalisando precisa de tempo para dizer. O tempo do qual o sujeito precisa é aquele que incide na falha, que retroage sobre sua falta fundamental, que lhe estrutura, dividindo-o.

A fala se alastra por poder evocar significantes do Outro, concernentes ao sujeito. Ela evoca mais do que informa, o efeito produzido pela fala pode ser no sentido do não-sentido (non-sens). Nesse sentido, o dizer é livre. Caso possamos assentir à liberdade do dizer, os efeitos significantes se farão ressoar, esta é a aposta para o tratamento psicanalítico. Lacan lembra-nos de que o psicanalisando vai à análise para se dizer, mais do que para se instruir, e que o psicanalista suporta por tempo suficiente o tempo do qual o psicanalisando precisa para isso.

A temporalidade da psicanálise é composta de furos, de descontinuidade. O tempo que concerne ao inconsciente oferece estofo ao ser. Um estofo para o ser, longe 
de ser uma imagem, é um corpo de linguagem, no qual também não encontraremos todo o ser, apenas o que puder ser corpsificado $\left(\operatorname{corps}(e)\right.$ ification $\left.{ }^{31}\right)$. O imaginário serve ao ser por não mostrar toda a realidade, por falhar em revelar tudo de uma vez. O dizer toca o ser, na medida em que há sempre um fosso entre o que o sujeito enuncia e o fato de ser ele que o enuncia. O ser advém daí, do que não se fecha no dizer. Escorre pelo dizer aquilo que do ser resiste à simbolização. O impossível de ser simbolizado impossível de ser — é o limite pelo qual se instaura a categoria do real. Na análise, trata-se de, oportunamente, produzir o sujeito como efeito da linguagem e de fazer nascer o ser como falha do dizer. Trata-se de um aqui (hic) que se faz agora (nunc), propiciado pelo momento de concluir o tempo para compreender o instante de olhar.

\footnotetext{
${ }^{31}$ Termo usado por Lacan no seminário Mais, ainda (1972-1973) para designar o corpo tomado de linguagem.
} 


\section{Capítulo 3}

\section{Considerações sobre o que se faz com o tempo - em Freud e Lacan}

O que estou buscando agora é o tempo. (Philip Glass, curta-metragem What are you looking for?)

\subsection{Urgência do ato}

As elaborações de Freud e Lacan acerca da temporalidade possuem longo alcance na teorização de ambos. Buscaremos, neste capítulo, explorar parte desse alcance, isto é, qual a incidência que o tempo, inerente à constituição do sujeito, terá no uso de alguns conceitos e categorias concernentes à psicanálise, quais sejam: o ato, o pensamento, a verdade, o saber e a castração. Com esse intuito, utilizaremos principalmente os seminários $O$ ato psicanalítico, $O$ avesso da psicanálise e Mais, ainda de Lacan, bem como os artigos "Radiofonia", também de Lacan, "Sobre a transitoriedade", "Análise terminável e interminável”, “A cabeça da Medusa" e “Construções em análise”, de Freud.

Lacan encerra a dissolução do sofisma dos três prisioneiros em "O tempo lógico e a asserção da certeza antecipada" ressaltando a ocorrência de um ato, necessário à conclusão do problema lógico, pois o sujeito se precipita em ato no momento de concluir sobre si. O ato, proveniente de uma urgência vivenciada pelo sujeito, terá repercussões mais abrangentes na teoria lacaniana. Iniciaremos este capítulo abordando o que vem a ser o ato necessário para a asserção do sujeito da enunciação, partindo principalmente das elaborações de Lacan no seminário $O$ ato psicanalítico $^{32}$.

\footnotetext{
${ }^{32}$ Seminário ainda não publicado oficialmente. Utilizamos para este trabalho uma versão extraoficial, traduzida para o português.
} 
Podemos identificar nesse seminário uma definição possível de ato em psicanálise, pela relação que Lacan (1967-1968) estabelece entre ato e origem: "Um ato é ligado à determinação do começo, e muito especialmente, ali onde há a necessidade de se fazer um, precisamente porque não existe" (p. 78). Se tomarmos essa definição como norteadora, perceberemos que a origem aqui evocada é uma anterioridade lógica. $\mathrm{O}$ ato funda uma experiência que será admitida como inaugural a posteriori, que se realiza na urgência do presente para fundar o passado no futuro, tal como a função da pressa ${ }^{33}$ no sofisma dos três prisioneiros.

Diferentemente do que caracteriza qualquer ação habitual, um ato marca a diferença entre o que havia antes e o que houve depois; é divisor, traz algo novo. Lacan acrescenta que o ato se constitui por uma inscrição, como um correlato de significante. A inscrição confere-lhe caráter inaugural, ou seja, produz um nascimento. A novidade proclamada por um ato só pode surgir, entretanto, se houver também uma perda. A perda é necessária para existir começo e fim, um ato ata o começo ao fim, de modo que possa existir ainda recomeço e reato. Por estar remetido à origem, o ato revela algo da ordem da verdade, inaugura uma verdade para o sujeito.

Lacan nota que Freud identificou as pistas relativas à verdade dos processos psíquicos em caminhos errantes. Os erros não foram encobertos ou consertados, mas evidenciados, por se tratarem justamente da direção encontrada. Pudemos notar também esse percurso freudiano no primeiro capítulo deste trabalho, com o que foi proposto a partir da Spaltung existente no aparelho psíquico. Os primeiros passos da psicanálise percorreram um campo aberto pelos lapsos: por atos falhos, tropeços na língua e recordações interrompidas, ou seja, pela falha no dizer. Freud chegou a apontar que os

\footnotetext{
${ }^{33}$ Torres (2010), em Dimensões do ato em psicanálise, explora os efeitos da pressa existente no ato, evidenciando-os como passagem, travessia e destituição.
} 
esquecimentos eram um realce do material inconsciente. Ele prosseguiu com as pesquisas acerca da vida anímica observando o que se perde com a linguagem.

Lacan, seguindo as pistas de Freud, indica-nos a dimensão da perda na experiência psicanalítica num ponto de ser, presente em um “eu perco" pronunciado pelo psicanalisando. O psicanalisando está ali em busca de algo que perdeu, um objeto primordial, conforme inferia Freud, mas o que acha é mais uma vez a falha, no momento presente da fala, pela perda de palavras, de significados, de imagens. Atrás daquilo que perdeu, ele encontra sua falta, visto que não havia nada ali; é uma falta que propicia essa busca.

O objeto perdido não é, para Lacan, objeto do desejo, mas objeto causa de desejo. Esse objeto, designado pela letra $a$ no seminário $A$ angústia, não pertenceu ao sujeito em algum momento e foi depois perdido: ele está em falta desde o início. Lacan situará o objeto $a$ no princípio do ato, o qual, por sua vez, terá como efeito o sujeito dividido. O sujeito depende dessa causa que o faz dividido, sendo o ato uma autenticação dessa relação. O sujeito não poderia ser a causa de si; ele é efeito de uma perda, é isso que se presentifica num ato.

Lacan evoca o ato psicanalítico como um definidor importante do campo da psicanálise por instituir um fim e promover uma virada, propiciando a emergência do sujeito e, no instante mesmo do ato, o seu apagamento ou mesmo a sua destituição. O ato será frequentemente reconhecido por Lacan como uma forma refinada, cortante, de intervenção do psicanalista. Além disso, de acordo com o que vislumbra nesse seminário, o ato poderá ser tomado como um dos sinais, do lado do psicanalisando, de que o sujeito levou a cabo sua análise, pela consequência modificadora que sua ocorrência acarreta. $\mathrm{O}$ ato possibilita uma transformação que, passado o momento de desvanecimento, poderá mobilizar no sujeito uma criação. 
No que se refere à constituição subjetiva que culmina na precipitação do sujeito em ato ao antecipar a asserção de uma certeza sobre si, como vimos no capítulo anterior com o tempo lógico, depreende-se que um ato pode ser um dizer que toca a verdade. A maneira pela qual o ato incide no tratamento psicanalítico acentua a dimensão temporal que lhe é própria. Ao percorrer o caminho que permite um ato, o sujeito é, desde então, a verdade desse ato que lhe concerne propriamente.

Um ato só é possível depois de transcorrido tempo para compreender; entretanto, subverte a compreensão, inverte o que poderia ser uma espera mortífera - como faz o neurótico obsessivo, por exemplo, quando, em vez de estar ali presente, está no momento antecipado da morte do mestre. No ato, momento no qual o sujeito se apaga para nascer de novo, trata-se de romper a espera para fazer precipitar uma certeza antecipada de si, não do outro. Um ato se torna efetivo pelo discurso: poderíamos dizer que os resultados na análise, seus efeitos de discurso, compõem uma dimensão de liberdade que se atinge em ato, não em potência, e que concerne ao corpo presente. Sob esta perspectiva, a liberdade se efetiva no momento atual, na urgência de concluir, tal como fora conquistada pelos três prisioneiros.

\subsection{O que se perde com o tempo}

O que se perde com a transitoriedade? É a pergunta que Freud (1914-1916) suscita no artigo "Sobre a transitoriedade", tendo em vista um limite encontrado na fruição, no prazer do ser humano. Ele observa o resultado incontornável de um tempo que escorre, a duração das coisas se esvai lançando o sujeito em um trabalho sobre a perda do objeto. Temos aqui uma direção importante sobre a concepção freudiana de 
temporalidade, lembrando que há aquilo que passa e também o que não passa com o tempo, conforme tentamos explorar de modo dialético no capítulo anterior.

De acordo com Lacan, em $O$ ato psicanalítico, o sujeito se ilude, por algum tempo, afirmando-se na pretensão de apreender algo como todo, engana-se ao pretender ser suporte eventual de algo que é inteiro, por supor que possa pensar a si mesmo como sujeito do conhecimento. Porém, o psicanalisando não é sujeito por inteiro, é dividido. Em psicanálise, um sujeito não será completamente sujeito, nem será sem objeto. O objeto só poderá ser rejeitado para ser situado na relação com o desejo do Outro, como o que cai dessa relação, na causa de uma cisão entre ambos.

O sujeito, distinguindo-se do ser, mas referindo-se a ele, advém na análise pelo discurso instituído na associação livre, que, por sua vez, solicita que o sujeito aí se demita, abdicando de si mesmo. O psicanalisando aceita perder-se na linguagem para poder reencontrar-se nela novamente. Ele é quem experimenta os efeitos da palavra ao falar: "seu discurso, tal como regrado, instituído pela regra analítica [associação livre], é feito para ser a prova de que, como sujeito, ele já está constituído como efeito da palavra" (Lacan, 1967-1968, p. 128). A regra fundamental estipula uma tarefa — que o sujeito se ausente - para que ele não comande o curso do que será dito, mas se deixe levar pelo dizer.

O objeto $a$ opera na análise produzindo deslocamentos e deslizamentos em torno dele mesmo, de forma que ele seja o saldo da operação que promove se mantendo como resto $^{34}$. Este $a$ resta por resistir a qualquer representação, opera a partir da falta real no corpo, tal como os resíduos da análise que Freud (1937) destaca em “Análise terminável e interminável". Para ele, a transformação nunca é completa, "Há quase sempre

\footnotetext{
${ }^{34}$ Chatelard (2005), em $O$ conceito de objeto na psicanálise: do fenômeno à escrita, sublinha que a análise é uma experiência de perda. Ela salienta que o objeto causa de desejo se refere ao que o sujeito tem de mais singular, àquilo que lhe permitirá ser subtraído gradualmente da cifra do Outro.
} 
fenômenos residuais, uma pendência parcial” (p. 244). Há algo de interminável na análise, um resíduo de sintoma.

Lacan (1966-1967), antes de se reportar ao ato psicanalítico, indicou uma relação entre a repetição e a dimensão do ato, referindo-se à atualização de uma perda. Tal relação merece ser considerada neste capítulo, em função da temporalidade a ela conferida, pois a repetição não é um mandamento do passado: "Ela [a repetição] é o ato pelo qual se faz, anacrônica, a imisção da diferença trazida no significante. Aquilo que foi, se repetido, difere, tornando-se tema [sujet] a ser reeditado.” (p. 326) A repetição pode encontrar ponto de basta na análise e ainda assim ser um caminho de recriação, pois é o que o sujeito tem de singular que se repete. $O$ sujeito se institui como representado por um significante-mestre (S1) para outro significante $(\mathrm{S} 2)$, de forma que na passagem de um significante ao outro haja uma perda, de onde vem a função do objeto perdido, em torno do qual deslizará os significantes. O sujeito repete essa passagem, atualizando essa perda.

Lacan (1967-1968) mostra que esse ponto de inflexão funda a ilusão de um objeto perdido, cuja busca recairá sobre a função mediadora do objeto $a$, situado entre o significante original, recalcado, e o significante que representa o sujeito numa substituição instauradora da repetição, que terá sempre caráter de primeira vez. A repetição, como vimos, guarda estreita relação com o tempo, no que concerne ao ritmo próprio ao movimento desejante do sujeito. Nesse sentido, um ato possui caráter de repetição, por realizar a imissão da diferença no único lugar que poderá ser sempre o mesmo, no real.

Existe um fracasso parcial da análise, pois não é possível haver remissão de todos os sintomas, algum traço do psicanalisando irá permanecer. Aquilo que fez com que ele procurasse a análise não se extingue completamente e o motivo que tem para 
tratar-se resiste, em parte, ao tratamento. Essa parte intratável de si sobra e é o que o sujeito reconhece de originalmente seu, isso que se atinge parcialmente na análise é de fato a conquista do sujeito. Ele encontra sua metade sem outra metade, pois ele é essa parcialidade, e é isso o que Lacan sublinha com a clivagem, a Spaltung freudiana. Um paciente procura a análise para se livrar de seus sintomas, de seu sofrimento, e encontra alguma liberação no dizer. O dizer não the faz livre de si mesmo, nem livre de desejo, mas talvez livre para desejar.

\subsection{Tempo para não pensar}

A temporalidade é apreendida de forma contundente na expressão freudiana "Wo Es war soll Ich werden", contida no artigo "O Eu e o Id", que Lacan sugere por diversas vezes que seja traduzida da seguinte maneira: lá onde isso estava, [eu], sujeito, devo advir. No seminário $O$ ato psicanalítico, Lacan insistirá na observância dessa expressão e na abrangência que ela confere ao conceito de inconsciente. Como vimos, o inconsciente se apresenta por um batimento em ruptura com o cogito cartesiano - "se eu penso, eu sou”. Lacan (1967-1968) indaga: “Será que nesse ‘eu penso', eu aí estou?” (p. 81). Não exatamente, pois "lá onde mais certamente eu penso, ao me dar conta disso, eu lá estava” (p. 82). Lá onde isso estava, onde não está mais senão lá, porque eu sei que eu o pensei, devo advir como sujeito.

Freud (1937) observa, de forma acurada, em "Construções em análise”, que a verdade concernente às construções obtidas na análise por diversas vezes se confirma pela frase "Nunca pensei isso", proferida pelo analisando. Tal frase pode ser convertida em uma constatação do inconsciente: lá onde não penso, lá no inconsciente, advenho 
como sujeito. O inconsciente é apreendido por um "eu não penso", é o que demonstra Lacan (1967-1968):

\author{
Para estar lá como inconsciente, não é necessário ainda \\ que eu pense, como pensamento, em que consiste seu \\ inconsciente. Lá onde eu o penso, é para não mais estar \\ em mim. Eu não estou mais aí. (p. 83)
}

Dessa formulação freudiana, da qual advém o sujeito do inconsciente, Lacan retira a seguinte proposição: “ou não penso, ou não sou”. O “eu não penso”, inscrito em um ponto de partida estruturador, denota uma forma de sujeito que aparece como que arrancado do lugar a ele destinado. Já a implicação do ser no sujeito está presente em uma ambiguidade lógica, a de que o sujeito pode funcionar como não sendo: “[...] o ser tal como ele pode surgir de qualquer ato que seja, é ser sem essência como são sem essência todos os objetos ' $a$ ”' (Lacan, 1967-1968, p. 91).

Para atingir a dimensão do ser, é preciso deixar de ser, de-ser, como propõe Lacan. O sentido carrega o peso de ser, mas isso não basta para lhe dar existência. É preciso que o ser escape do sentido pleno para de fato ser, não sendo estritamente. Daí o valor de um ato falho para a psicanálise, pois, se ele interrompe o curso da fala, fazendo com que o sentido nos escape, ele será bem-sucedido.

Ao psicanalisando, é solicitado que diga tudo o que lhe ocorrer, por mais confuso ou sem sentido que pareça, por mais que possa demonstrar que ou ele não pensa ou ele não é, pois o que for produzido ali será válido. Por mais que se demonstre a Spaltung, produz-se algo, porque é disso mesmo que se trata na análise, de demonstrar 
que é a Spaltung que propicia qualquer produção, devido a uma falta que está na sustentação da existência. O dizer $e x-$ siste $^{35}$ a qualquer dito que seja.

\subsection{Saber e verdade em relação ao tempo}

Lacan aponta, ao longo de seus seminários, uma relação entre saber e verdade a partir da constituição subjetiva, visto que o sujeito se constitui na busca de sua verdade e tem no saber um meio de tocá-la. Abordaremos essa relação, apoiando-nos no artigo "Radiofonia" e nos seminários $O$ ato psicanalítico, $O$ avesso da psicanálise e Mais, ainda, a fim de examinar alguns aspectos da dinâmica temporal envolvida.

No seminário $O$ ato psicanalítico, Lacan caracteriza o saber, distinto do conhecimento, como aquilo que circunscreve o real, não a realidade. Por isso, o saber é tanto possível, como impossível. Não é de um "conhece-te a ti mesmo" que se trata, mas da apreensão do curto alcance dessa pretensão, por existir um limite no pensamento consciente. Tal limite está inscrito no efeito de linguagem, que sempre deixa algo de fora, conforme elucida Lacan (1967-1968):

Em consequência [do limite da linguagem], enquanto permite ao sujeito constituir-se como tal, essa parte excluída faz com que o sujeito, por natureza, ou bem não se reconheça senão ao esquecer o que primeiramente o determinou nesta operação de reconhecimento, ou até, ao

\footnotetext{
${ }^{35}$ Ex-sitir é um termo híbrido usado por Lacan para tentar exprimir a exclusão enquanto parte intransponível da existência. Como esclarece Leite (1994), em Psicanálise e análise do discurso - o acontecimento na estrutura, o termo ex-sistência foi forjado por Lacan para fazer referência à dimensão real, excluída com o advento da ordem simbólica.
} 
se apreender nesta determinação, a denegue, quero dizer, só a veja surgir em uma Verneinung essencial, ao desconhecê-la. (p. 218)

Um discurso molda a realidade ao promover uma divisão entre o que o sujeito enuncia e o fato de ser ele mesmo quem enuncia ${ }^{36}$. Para Lacan, “ou não penso, ou não sou" é uma formulação dirigida ao saber. Mas onde estava o saber antes que nós o soubéssemos? Será que podemos considerar alguma dimensão nova e, ao mesmo tempo, sabida desde sempre? Lacan sugere que nos perguntemos se o que se sabe era sabido antes e se o que se diz era verdadeiro antes. Perguntar sobre o saber é se dirigir à origem e recair inevitavelmente em uma anterioridade que só existe logicamente. Saber e verdade não são, portanto, complementares, não compõem um todo, mas a verdade se amarra ao saber.

Lacan define saber e verdade, a partir de uma alternância entre ambos, indicando a fronteira de um e pela outra: "saber, em certos pontos que podem certamente ser sempre desconhecidos, faz falha. E são precisamente esses pontos que, para nós, estão em questão, sob o nome de verdade" (Lacan, 1967-1968, p. 56). A verdade está onde o saber falha, na direção de uma cisão (Spaltung), de modo que não há meios de tratar dela como tal. Disso decorre que, para a verdade, não há remédio: é incurável ${ }^{37}$.

No saber suposto ao analista pela transferência, trata-se somente de um saber haver-se (savoir y faire) com a verdade, no que ela pode ter de relação com a castração. Assim, conforme Lacan adverte em "Radiofonia", não se deve incitar o amor à verdade,

\footnotetext{
${ }^{36}$ Leite (1994) aponta que essa divisão entre enunciado e enunciação, que incide sobre o sujeito, é precisamente o que impede a sua substancialização na psicanálise.

${ }^{37}$ Maesso (2013), em O diagnóstico, seu avesso e a posição do psicanalista, desenvolve o que seria para o sujeito ser acometido por sua verdade e ter seu sofrimento de verdade reconhecido pelo psicanalista. A verdade, que tem um lugar na psicanálise, constitui-se na medida em que a fala progride.
} 
pois não há relação amorosa com a verdade: “É que, da verdade, não temos que saber tudo. Basta um bocado" (p. 442). O efeito de verdade é proveniente do que cai do saber, do que se produz nele: "a verdade situa-se por supor o que do real faz função no saber, o que se acrescenta a ele (ao real)" (p. 443), sendo esse justamente o limite da verdade por ser também um impasse.

Lacan (1972-1973), no seminário Mais, ainda, assinala que esperamos produzir em psicanálise um saber sobre a verdade. $\mathrm{O}$ analista interroga com o saber o que é da ordem da verdade. Lacan procura dissipar a confusão que pode existir entre verdade e real, pontuando que a verdade visa ao real, mas tem origem simbólica, diz respeito ao início marcado pelo traço unário, a isso que foi originariamente recalcado. Há uma propensão no saber, depois de ser constituído, a esquecer-se da verdade em sua forma nascente; é o que se estabelece com o recalque. Toda verdade é, portanto, o que não se pode dizer. Segue a direção da proposta psicanalítica:

[...] reter a verdade côngrua, não a verdade que pretende ser toda, mas a do semi-dizer, aquela que se verifica por se guardar de ir até à confissão, que seria o pior, a verdade que se põe em guarda desde a causa do desejo.

(Lacan, 1972-1973, p. 100)

A Nachträglichkeit (a posteriori), necessária ao recalque primário e secundário, como exploramos no primeiro capítulo, intervém de maneira incisiva na relação do saber com a verdade. Sem os significantes que compõem o saber no campo do Outro num só-depois, não haveria indicação da verdade. Dessa forma, para o sujeito, quem pode saber a verdade é o Outro. Por ser tesouro do significante, o Outro é o lugar do 
saber. Entretanto, uma certeza, uma referência à verdade, poderá ser antecipada em um ato, sem o saber do Outro.

Lacan (1969-1970), ao afirmar no seminário O avesso da psicanálise que o discurso possui uma estrutura que ultrapassa a palavra, convida-nos a creditar à estrutura o surgimento de alguma verdade. Nesse seminário, ele situa a verdade em uma posição no discurso, sob a barra, ao lado do agente. Explica-nos também que um significante-mestre, o recalcado original - S1 - representa algo, o sujeito, no campo do saber - S2, uma bateria de significantes ${ }^{38}$.

Uma vez que S1 tenha surgido em um primeiro tempo, S2 passará a repeti-lo. Na repetição constará a perda do objeto, que cai nessa fenda entre uma função significante primária e a rede de significantes que lhe é posterior na constituição. Isso denota, para Lacan, que o saber é escandido pelo significante, ou seja, não pode ser inteiro. Não há, assim, saber absoluto, saber que se sabe saber, mas um saber-fazer (savoir-faire) com aquilo que diz respeito ao inconsciente. O trabalho na análise, por meio do saber, adquire um sentido obscuro, justamente o sentido da verdade. O saber, que não é total, é sabido por meio de um enigma, explica-nos Lacan, pois um enigma não passa de uma enunciação, cuja função é semidizer a verdade ${ }^{39}$.

${ }^{38}$ Os lugares definidos por Lacan no discurso são:

$$
\frac{\text { agente }}{\text { verdade }} \rightarrow \frac{\text { outro }}{\text { produção }}
$$

Já os termos que ocuparão esses lugares, girando de um discurso para o outro são: S1, S2, \$, a. Quatro discursos serão formados por um quarto de giro: discurso do mestre, discurso da histérica, discurso do analista e discurso universitário.

${ }^{39}$ Maesso (2013) oferece indicações sobre a relação entre saber e verdade, no discurso psicanalítico* em especial, ressaltando o semidizer como forma possível de veicular verdade no saber, ou seja, posicionar discursivamente o saber no lugar da verdade.

*Dentre os quatro discursos formalizados por Lacan no seminário $O$ avesso da psicanálise, está o discurso psicanalítico (do analista), sob a seguinte notação:

$$
\frac{a}{\mathrm{~S} 2} \rightarrow \frac{\$}{\mathrm{~S} 1}
$$


Freud (1937), em “Análise terminável e interminável”, pergunta-se sobre o que permanece e o que muda após uma análise, de forma que o permanente não seja necessariamente uma cura. Ele reconhece que a verdade acarreta desprazer, de tal forma que precisa ser sacrificada pela consciência na constituição psíquica. Em virtude disso, temos nossa percepção falseada, além de possuirmos representações imperfeitas e deformadas do isso, do que se passa no inconsciente. Ainda assim, a verdade só se efetiva na convicção da existência do inconsciente, porque é justamente dali que se fala alguma verdade, de modo lacunar, é claro, mas não menos verdadeiro. Esta meiaverdade esbarra na castração, que se faz presente tanto no homem como na mulher pelo que Freud chama de "grande enigma do sexo". Tal enigma não é removido nem respondido na análise, mas revisitado pelo sujeito, que se vê convocado a mudar de posição frente à questão acerca do órgão em falta; para Freud, a castração resiste à análise.

Na tragédia edípica, elevada ao estatuto de mito na psicanálise, o oráculo ${ }^{40}$ não fornece uma resposta àquele que se dirige a ele, pois a maneira pela qual ele enuncia o enigma já é a resposta; é importante para a transmissão de uma verdade que ela seja mantida no nível da enunciação, não do enunciado. O que o sujeito pode dizer não equivale à sua verdade, ao recalcado original, pode se aproximar dela, rodeá-la, tocarlhe, mas não sê-la; pois não há outra solução senão a palavra, e, como há falta na palavra, ou seja, ela não pode se dizer a si mesma, ela será semidita. A verdade diz respeito a uma indeterminação do sujeito, concerne a sua falta fundamental intransponível - à qual um órgão ou uma palavra em falta se remetem. Ainda assim seria possível, de alguma forma, sabê-la?

\footnotetext{
${ }^{40}$ Édipo recorre ao oráculo para saber de seu destino e seguir sua direção, na tragédia Édipo rei, de Sófocles.
} 


\subsection{Origem de volta}

Lacan, no seminário $O$ avesso da psicanálise, discorre sobre algumas conexões entre verdade, castração, morte e origem. Para ele, a constatação de que a verdade só se sustenta em um semidizer encontra maior alcance na estrutura dos mitos, pois o que vem no começo, ao menos o que se pode narrar, é o mito. Lacan relaciona verdade, castração e morte à origem do sujeito através da passagem do mito à estrutura. Considerando o percurso teórico-conceitual que realizamos até aqui, tentaremos, neste momento do trabalho, traçar algumas considerações, seguindo Freud e Lacan, que nos possibilitem ligar uma questão acerca da castração à origem do sujeito.

A concepção psicanalítica de verdade, proveniente de um semidizer, pode nos auxiliar a interrogar o que vem a ser a castração para o sujeito em análise. Esta noção de que a verdade se enuncia em um enigma, fora desenvolvida por Lacan (1956-1957) no seminário A relação de objeto ao atribuir aos mitos uma função de articular a verdade. O mito se apresenta como uma narrativa ficcional e obedece a uma estrutura; no entanto uma ficção mítica mantém relação com uma verdade, de forma que a veicula sob algum disfarce. A verdade tem, para Lacan, uma estrutura de ficção: “A necessidade estrutural que é carreada por toda expressão da verdade é justamente uma estrutura que é a mesma da ficção.” (p. 259)

A estrutura do mito parece condicionar certos aspectos dos seres humanos de difícil apreensão discursiva, Lacan ressalta temas de vida e morte, de existência e nãoexistência e de aparição daquilo que ainda não existe. Assim, os mitos se reportam a questões sobre o nascimento do homem e do universo que denotam um saber sobre a 
origem $^{41}$. Em psicanálise, a origem é abordada miticamente e logicamente, alcançada num só-depois, de acordo com o que desenvolvemos ao longo deste trabalho.

A questão sobre a origem nos remete a questão sobre o fim, e vice versa. Com isso, é possível estabelecer uma relação de referência mútua entre nascimento e morte. Para, Freud, a pulsão de morte é original; porém, não é a morte do organismo vivo que o leva a identificá-la, e sim a vivência humana, os fenômenos de repetição principalmente. Há um princípio, além do princípio de prazer, que se refere à morte, mas pelos caminhos da vida. Estar prometido para a morte faz parte da vida, é pela via da existência que se pode ir em direção à morte, ser o próprio inacabamento, ser falta-aser: "a vida só retorna aí pelos mesmos caminhos de sempre, que ela uma vez traçou" (Lacan, 1969-1970, p. 17).

O retorno do recalcado traz com a marca original uma dimensão impossível de ser simbolizada, sinalizando a existência do real. Freud indica que o principal limite da psicanálise é justamente essa tendência para a morte, pois não há tratamento possível à pulsão de morte, o que nos permite admitir que na origem algo morra para que o sujeito nasça. Essa morte em vida encontra expressão na experiência que o sujeito tem da castração. Segundo Lacan (1967-1968), a castração pode ser compreendida como a experiência subjetiva de uma falta encarnada. Lacan (1953), em "Função e campo da fala e da linguagem", anunciou a necessidade e a irreversibilidade da morte na estrutura: “o símbolo se manifesta inicialmente como assassinato da coisa, e essa morte constitui no sujeito a eternização de seu desejo" (p. 320).

A morte está na origem, conforme Lacan elucida, na medida em que o traço unário é uma marca para a morte. No entanto, ninguém, dentre os vivos, sabe o que ela é. Aí reside um valor de refutação a ser considerado: “é indispensável para a vida que

\footnotetext{
${ }^{41}$ Werner (2013), na introdução de Teogonia, aponta que, para os gregos do período arcaico a origem dos deuses - teogonia - e a origem do universo - cosmogonia - são inseparáveis. Para se referir a um saber acerca da origem, era preciso recorrer aos mitos.
} 
alguma coisa irredutível não saiba" (Lacan, 1969-1970, p. 129). Em nome dessa alguma coisa que não sabe disso, o sujeito também não o sabe, nem quer saber.

A proximidade da castração com a morte foi delineada por Freud (1922) em "A cabeça da Medusa”, quando recorreu a um mito para elucidar a estrutura psíquica. A terrível cabeça decapitada de Medusa, monstro mitológico ${ }^{42}$, produz um enredo ao horror da castração. A decapitação alude a um destacamento do corpo, talvez a cabeça da Medusa seja deveras assustadora porque não é um corpo sem uma parte, mas uma parte sem o corpo. Ela é a figuração da ausência, do que caiu e ficou de fora, e só mesmo no mito isso é possível.

A ausência é a causa do horror, diz-nos Freud. Ficamos paralisados diante de uma imagem que não se enquadra, que se abre para um ponto de fuga inassimilável, como que petrificados diante da cabeça da Medusa: "O terror da Medusa é assim um terror de castração ligado à visão de alguma coisa" (Freud, 1922, p. 289). Essa fixidez da imagem imobiliza o espectador e, por isso, exige um tempo a mais para, na tentativa de compreendê-la, ir além dela, para que se possa produzir alguma maleabilidade no espectador. Fica-se paralisado diante da castração, num instante de ver que necessita ser seguido de um tempo para compreender e de um momento no qual se possa concluir algo sobre a ausência no que foi visto.

A possibilidade de conclusão sobre aquilo que se viu em um instante fugaz, após um período de compreensão transcorrido, indica a passagem da castração ao desejo. Esse percurso lógico, propiciado por modulações temporais, é o movimento em torno da falta fundamental e intransponível que engendra a estrutura. Resta ao sujeito mover-se

\footnotetext{
${ }^{42} \mathrm{O}$ mito da Medusa é contado em Teogonia (Origem dos deuses) de Hesíodo (séculos VIII/VII a. C.). Medusa é uma criatura monstruosa - estranhamente mista - filha da deusa Terra. Ela não é uma divindade e não pode ser conquistada pelos mortais, é tida, por isso, como uma criatura impossível (amêkhanos).
} 
para poder contornar a falta, ou, caso contrário, ficaria fisgado, sem poder diferenciar nada do espectro visto, sem fazer da visão a função de olhar.

Como sugere Lacan (1970) em "Radiofonia", a foice do tempo tem efeito sobre a castração, as marcações temporais são escansões realizadas sobre o sujeito, é assim que o sujeito conta o tempo ${ }^{43}$. Podemos dizer que o movimento lógico-temporal, realizado em torno da falta, propulsiona o desejo do sujeito. $\mathrm{O}$ desejo pode ser concebido como o que se traduz da castração, é ter feito da castração um sujeito.

Lacan, no seminário $O$ ato psicanalítico, descreve o instante de ver, como um momento de emergência, fulminante, entre dois mundos, onde surge o sujeito barrado e seu objeto $a$. Disso depreende-se a necessidade de um tempo para compreender, para que se possa sair desse espaço, 'entre', e retornar a ele com uma dialética conquistada entre sujeito e objeto. $\mathrm{O}$ momento de concluir retroage sobre o instante de olhar, cabe salientar que ambos não são iguais, é um momento após o outro; pois para que houvesse qualquer torção, qualquer mudança subjetiva, o tempo para compreender teve que escoar, isto é, um intervalo interveio para que o sujeito da enunciação emergisse.

Vale a pena destacar ainda o que Lacan entende por experiência subjetiva da castração, essa modalidade de falta própria ao campo psicanalítico, isto é, de uma falta que se encarna: "É, a saber, que o sujeito realize que ele não tem, ele não tem o órgão do que chamaria o gozo único, unário, unificante” (p. 98). O sujeito não tem o órgão daquilo que se extrairia o gozo unificador, não havendo, portanto, realização possível do sujeito como parceiro sexuado no que se imagina como união sexual, unificação na cópula.

É isso que Lacan sublinha ao dizer que não há relação sexual, ou seja, que não há relação sexual articulável pelo significante. Como o sujeito é representado por um

\footnotetext{
${ }^{43}$ Chatelard (2005) auxilia-nos entender qual a relação do tempo com saber e verdade, indicando que o saber do inconsciente culmina em uma verdade que emergiu da foice do tempo, uma verdade do sujeito, de sua realidade psíquica, de sua falta.
} 
significante para outro significante, não há assim representação possível para a união entre dois seres sexuados. A não-relação sexual pode ser compreendida como um limite da subjetivação, semelhante ao "grande enigma do sexo" com o qual Freud se deparou, pois a relação é irrepresentável. Existe uma dimensão real nesta impossibilidade de relação, que confere ao sujeito uma experiência de que lhe falta algo e lhe aponta uma verdade.

Lacan (1956-1957), no seminário A relação de objeto, abordou a experiência da falta sob três formas, em referência aos registros real, imaginário e simbólico: a privação, enquanto ausência real, um furo; a frustração, enquanto dano imaginário; e a castração, enquanto dívida simbólica. A castração, estabelecida em relação a uma lei simbólica, com a dissolução do complexo de Édipo, retroage sobre a privação e a frustração. A castração advém na constituição do sujeito como uma saída no simbólico frente às insuficiências da relação entre sujeito e objeto. Lacan acentua que o complexo de castração é, para aquele que não é paranoico, a saída para a situação relacional na qual o sujeito é uma presa das significações do Outro. Com a introdução da ordem simbólica, através da interdição do incesto no Édipo, o assunto sai das mãos da criança e vai ser resolvido alhures, no âmbito da lei.

Abordar a castração em psicanálise tem o sentido de voltar à origem na tentativa de recuperar com enfoque um pouco diferente o que estava lá sob o nome de trauma ${ }^{44}$. Freud executa essa volta ao situar a experiência do trauma, do desamparo primordial, na angústia de castração vivida pelo sujeito no Édipo. O complexo de castração adquire, para Freud, sua forma final - temor pela perda do órgão - com a dissolução do complexo de Édipo, tornando-se o núcleo de toda formação sintomática nas neuroses. A angústia de castração incide sobre o registro de uma experiência traumática já existente,

\footnotetext{
${ }^{44}$ Chatelard (2003) ressalta que o saber é inventado para preencher o furo no real: "ali onde não há relação sexual, há troumatism" (p. 182). Aproximar-se de onde está o furo é chegar à borda do real, de modo que isso não pode deixar de ser traumático.
} 
inserindo o trauma na estrutura sem, com isso, emperrar o desejo. O complexo de castração acaba, na realidade, por condicionar o movimento do desejo. A castração, enquanto assunção de uma modalidade de falta, pode ser concebida em proximidade à noção psicanalítica de verdade, como aquilo que direciona uma busca do sujeito, levando-o a um ponto de origem.

A volta que se dá, passando pela origem, para só-depois advir uma novidade é executável apenas por meio de construções, que não farão mais do que semidizer o surgimento do sujeito. As construções, de acordo com as buscas empreendidas por Freud, fazem-se com todo tipo de material fragmentado oferecido pelo psicanalisando. No entanto, este trabalho minucioso de recolhimento de cacos recordativos é feito para se chegar a um produto incompleto — sabidamente incompleto —, ou seja, à construção de um fragmento, de um pedaço da história precoce do sujeito, de um ensejo para a sua fantasia.

Pretendemos encerrar esta apresentação teórica acerca do sujeito que se estrutura no tempo com a instigante recomendação freudiana de se construir fragmentos, em virtude dos efeitos de verdade e transformação que dela decorrem. A construção é feita, segundo Freud (1937) em "Construções em análise”, com "restos que sobreviveram", para formar, no fim das contas, o enquadre de uma cena breve na história do sujeito. $\mathrm{O}$ quadro que não pode ser lembrado, apenas construído, será curto e incompleto, pois o analista desconhece o que há para encontrar.

O movimento não é apartado do resultado que ele mesmo produz. A construção pode ser compreendida como uma técnica que considera amplamente a função de Nachtraglichkeit, de modo que produz uma verdade como efeito. As referências não se 
fixam de antemão, mas se constituem gradativamente e revelam a estrutura no sódepois $^{45}$. O sujeito só se constitui na fala, antes não há sujeito.

As construções na análise se remetem ao enigma do desejo do sujeito e possuem efeitos verdadeiros. A cena primária da fantasia primordial, em uma radicalidade construtiva, carrega uma verdade do sujeito, isto é, sua clivagem. A construção dessa história incompleta, dessa ficção, articula para o sujeito passado, presente e futuro de modo não-linear, insere-o em sua temporalidade. A falta que engendra o sujeito é o que lhe permite aceder a si mesmo, ao seu fragmento, uma vez que a asserção sobre si é dizer-se em uma descontinuidade. Poderíamos, com isso, concluir que dizer é lançar-se no tempo.

\footnotetext{
${ }^{45}$ Leite (1994) aponta a originalidade da teoria freudiana, considerando como fundamental a noção de Nachtraglichkeit. As relações entre estrutura e experiência apresentam-se em consequência dessa forma especifica de estruturação no só-depois.
} 


\section{Considerações finais}

Este trabalho foi o resultado de um esforço em assinalar a concepção psicanalítica de tempo na constituição do sujeito do inconsciente, a partir de Freud e Lacan. Buscamos inicialmente averiguar qual seria a relação do tempo com os achados freudianos. Identificamos uma centralidade da dimensão temporal na teoria e na clínica psicanalítica, visto que Freud incluiu a noção de Nachträglichkeit e nachträglich desde as mais precoces considerações conceituais do psiquismo até as últimas elaborações do pensamento psicanalítico. Em seguida, procuramos em Lacan a pertinência da temporalidade para o surgimento do sujeito, utilizando como base teórica principal o artigo "O tempo lógico e a asserção da certeza antecipada", por ser onde ele começou a dizer de um tempo lógico. Procuramos mostrar como ambas as concepções de tempo compõem a especificidade do trabalho psicanalítico e como se apresentam em função da descontinuidade.

O efeito do tempo teve caráter decisivo no funcionamento dos mecanismos psíquicos e na observação dos princípios que lhe são supostos. Freud ateve-se aos efeitos retroativos para estabelecer diversos conceitos e funções psíquicas, tais como o trauma, o recalque, a cisão psíquica, a repetição e mesmo o inconsciente. Lacan viu em Nachträglichkeit uma concepção temporal a ser considerada nas manifestações subjetivas e nos diversos âmbitos do tratamento psicanalítico. Ele enfatizou a lógica do a posteriori freudiana e ainda introduziu sua noção de après-coup, como se evidenciou, por exemplo, nas operações de alienação e separação.

A atenção que Freud conferiu ao trauma no início de suas investigações indica uma marca indecifrável deixada no corpo pela experiência precoce que irá ressoar ao longo da vida do sujeito. O traumatismo surge como um empecilho ao esclarecimento e 
como uma direção em relação à qual prosseguirá a psicanálise. Freud dirige-se àquilo que não está claro, de modo que se aproximar do que atrapalha a compreensão não torna o desconhecido compreensível, mas atinge-se outra coisa. É à outra cena que Freud se dirige, ao que está fora. Assim como a outra cena, o tempo que se apresenta a ele não transcorre homogeneamente, sem interrupções. O tempo que se faz necessário às observações psicanalíticas provoca estranhamento, é composto de pausas, alternâncias, furos e se faz por intervalos marcados por escansões na experiência, conforme Lacan nos ajudou a perceber nas sucessões temporais lógicas.

O aparelho psíquico é composto a partir de uma divisão fundamental e implicará a diacronia e a sincronia em seu funcionamento, uma vez que os sistemas e as instâncias psíquicas não se sobrepõem uma à outra. $\mathrm{O}$ aparelho freudiano comporta uma falha, não funciona completamente bem e, justamente por isso, é constituído por sistemas e instâncias que se formam a partir de um limiar, que possuem um núcleo de clivagem e portam características do que lhe originaram. Há um furo na estrutura psíquica que pode ser identificado como uma falta que a engendra e impulsiona o movimento necessário para o seu funcionamento. Lacan se servirá dessas observações freudianas como fontes de alguns dos fundamentos acerca do sujeito dividido, barrado, isto é, de um sujeito de linguagem.

O aparelho psíquico, cuja propriedade de conservação e liberação constrói percepções e memórias, se constitui através da busca por uma impressão anterior, uma satisfação esperada, uma identidade perceptiva, um afastamento de alguma situação hostil, ou, fundamentalmente, de algo que falta. O movimento proveniente dessa busca, que poderá se transformar em desejo, torna o tempo essencial ao funcionamento do aparelho. O movimento propiciado pela não-satisfação apresenta ao sujeito a dimensão 
do tempo, de forma que podemos pensar que, em função desse movimento que conjuga tempo e desejo, o tempo criará o desejo e vice-versa.

A análise da estrutura psíquica permitiu-nos identificar que seus mecanismos são acessíveis somente quando obtemos seus efeitos e os elucidamos no só-depois. A ênfase dada a essa concepção temporal recai sobre uma questão relativa à origem do sujeito. Por meio de alternâncias no discurso e nos processos psíquicos, dá-se uma volta em direção a essa origem; volta-se para a partida, para a falha que enseja o trabalho psíquico, e constata-se por retroação uma falta fundante.

Essas voltas são executadas também pelo sujeito; seus deslocamentos permitemlhe distanciar-se da origem carregando algum traço dela, como o "Made in Germany" sugerido por Freud em alusão a uma marca original. Partindo de Freud e seguindo com Lacan, notamos que a questão acerca da origem coloca o sujeito diante de uma questão acerca do fim. O fio do tempo produz uma tensão entre o início e o fim. Entendendo as coisas desse modo, é possível pensar em uma dialética temporal que liga os acontecimentos por meio de intervalos ao invés de uma linearidade homogênea. Essa marcação temporal é consonante ao estatuto do sujeito, esse efeito advindo no intervalo entre um significante e outro.

As voltas, os desvios, as interrupções, os retornos e os saltos, realizados durante um discurso são indícios de uma temporalidade específica da psicanálise que, ao serem tomados por Lacan em seu retorno à letra de Freud, adquirem relevo no que foi proposto com o tempo lógico. Os três tempos — instante de ver, tempo para compreender e momento de concluir — apresentados no sofisma dos três prisioneiros incluem na progressão lógica da constituição subjetiva a função do a posteriori, que sustentará a marcação do intervalo, essencial para a percepção da diferença entre um momento e outro. Lacan identificará também a função da pressa, culminante na urgência de um ato, 
para a efetivação do tempo lógico. A pressa será decisiva para a apreensão do inconsciente em ato, numa suspensão do tempo transcorrido e numa ausência de pensamento.

O tempo, inerente à constituição do sujeito, será determinante no tratamento psicanalítico. Lacan dedicou alguns de seus escritos e seminários a esta questão, colocando-a no âmbito daquilo que definiria o campo psicanalítico e sua ética. O passo dado por Lacan, ao oferecer à noção de temporalidade uma lógica concernente ao sujeito do inconsciente, o fez prosseguir de modo autêntico, ocupando-se do sujeito em questão na psicanálise. Os cortes temporais, que alteram a ordem dos acontecimentos e que produzem sentido ou não-sentido, farão parte da técnica, incidindo nas interpretações e atos do analista. A sucessão temporal obtida por escansões marcará a extensão e a frequência das sessões.

Os últimos seminários proferidos por Lacan $-O$ momento de concluir e $A$ topologia do tempo — foram relativos ao tempo, demarcando mais uma vez a pertinência dessa dimensão para sua teoria e clínica. Não avançamos até a abordagem lacaniana nesses seminários, mas procuramos ressaltar o destaque especial conferido por ele a essa questão em outros momentos da construção de seu pensamento. Neste ponto, por não ceder quanto à questão do tempo, ele encontrou percalços e demonstrou inventividade tanto na prática clínica quanto na formação do psicanalista.

Lacan salientou diversas vezes que o tempo concernente à psicanalise é o tempo do inconsciente, que pode ser concebido como um batimento — oscilação entre abertura e fechamento. O tempo da análise não corresponde a algum padrão fixado, é o tempo necessário para que surjam efeitos do inconsciente, ou seja, é o tempo de algo acontecer enquanto o sujeito diz. Isso porque o sujeito não está num lugar fixo, não possui uma 
significação derradeira, emerge no intervalo entre um significante e outro. Desse modo, o tempo concedido na análise possibilita ao psicanalisando surpreender-se.

Lacan ressalta que o psicanalisando está no lugar do sujeito, daquele que fala e experimenta os efeitos da palavra, pois ele aceita perder-se na linguagem para só-depois poder se reencontrar novamente na linguagem. O sujeito surge como que arrancado do campo a ele reservado: é importante que o psicanalisando ocupe esse campo, que não seja um mero atributo daquele que vai à análise. O sujeito emerge no discurso instituído pela regra da psicanálise — a associação livre — quando esta solicita a ele que aí se abdique de si mesmo e se deixe levar pelo dizer.

O descentramento no dizer do analisando ou o semidizer do analista não tornam o sujeito livre de si mesmo nem livre de desejo, mas talvez livre para desejar. A linguagem confere uma dimensão de perda a uma falta fundamental na estrutura do sujeito. Lacan identifica um ponto de ser na experiência obtida com um "eu perco" na análise. O sujeito do inconsciente é um efeito proveniente de uma estrutura de linguagem que se configura em uma alternância temporal, isso porque é conduzido, pela dialética de sua constituição, da alienação à separação. A forma pela qual ele se apropria do tempo, encadeando dialeticamente passado, presente e futuro, indica-nos que o que passa não parece ser exatamente o tempo, mas o sujeito.

O problema existente no sofisma dos três prisioneiros refere-se a uma liberdade que poderá ser conquistada pelo sujeito ao aceder a si. Podemos propor, detendo-nos no trabalho subjetivo, uma questão acerca da relação entre liberdade e tempo: o que se libertaria com o tempo? Essa questão encontra uma direção na enunciação do sujeito, no alcance que pode ter uma palavra, chegando a ultrapassar o pensamento, e na liberação do ser no dizer. 
Em psicanálise, há um deslocamento do eixo do saber, que está em outro lugar: lá onde não se pensa que possa estar. Ocorre um descentramento do discurso — da consciência para o inconsciente — de forma que a realização de uma liberdade não condiz tanto com o campo do esclarecimento, mas com o campo do desejo. Na análise as construções discursivas se remetem a um enigma acerca do desejo e possuem efeitos de verdade para o sujeito. Uma asserção sobre si na análise é dizer-se em descontinuidade, visto que a falta que engendra o sujeito lhe permitirá aceder a si. Nesse sentido, dizer seria lançar-se no tempo. Podemos pensar, com isso, que há uma liberdade conferida ao sujeito pela experiência de dizer: ao dizer sem pensar, um 'aqui' pode se fazer 'agora' pelo momento de concluir o tempo para compreender um instante de ver. 


\section{Referências bibliográficas}

Cassin, B. (2005). O efeito sofístico. São Paulo: Editora 34.

Chatelard, D. S. (2005). O conceito de objeto na psicanálise: do fenômeno à escrita. Brasília: Editora Universidade de Brasília.

Freud, S. (2006). Projeto para uma psicologia científica. Em Edição standard brasileira das obras psicológicas completas de Sigmund Freud. Vol. 1. Rio de Janeiro: Imago. (Original publicado em 1950 [1985])

. (2006). Estudos sobre histeria. Em Edição standard brasileira das obras psicológicas completas de Sigmund Freud. Vol. 2. Rio de Janeiro: Imago. (Original publicado em 1985)

(2006). Lembranças encobridoras. Em Edição standard brasileira das obras psicológicas completas de Sigmund Freud. Vol. 3. Rio de Janeiro: Imago. (Original publicado em 1899)

(2006). A interpretação dos sonhos. Em Edição standard brasileira das obras psicológicas completas de Sigmund Freud. Volume único. Rio de Janeiro: Imago. (Original publicado em 1900)

. (2006). Sobre a psicopatologia da vida cotidiana. Em Edição standard brasileira das obras psicológicas completas de Sigmund Freud. Vol. 4. Rio de Janeiro: Imago. (Original publicado em 1901)

(2006). Recordar, repetir e elaborar. Em Edição standard brasileira das obras psicológicas completas de Sigmund Freud. Vol. 12. Rio de Janeiro: Imago. (Original publicado em 1914)

(2004). À guisa de introdução ao narcisismo. Em Obras psicológicas de Sigmund Freud: Escritos sobre a psicologia do inconsciente. Vol. 1. Rio de Janeiro: Imago. (Original publicado em 1914)

(2006). Sobre a transitoriedade. Em Edição standard brasileira das obras psicológicas completas de Sigmund Freud. Vol. 14. Rio de Janeiro: Imago. (Original publicado em 1915)

(2004). O recalque. Em Obras psicológicas de Sigmund Freud: Escritos sobre a psicologia do inconsciente. Vol. 1. Rio de Janeiro: Imago. (Original publicado em 1915)

(2006). O inconsciente. Em Obras psicológicas de Sigmund Freud: Escritos sobre a psicologia do inconsciente. Vol. 2. Rio de Janeiro: Imago. (Original publicado em 1915) 
(2006). Luto e melancolia. Em Obras psicológicas de Sigmund Freud: Escritos sobre a psicologia do inconsciente. Vol. 2. Rio de Janeiro: Imago. (Original publicado em 1917)

. (2006). Além do princípio de prazer. Em Obras psicológicas de Sigmund Freud: Escritos sobre a psicologia do inconsciente. Vol. 2. Rio de Janeiro: Imago. (Original publicado em 1917)

(2006). História de uma neurose infantil. Em Edição standard brasileira das obras psicológicas completas de Sigmund Freud. Vol. 17. Rio de Janeiro: Imago. (Original publicado em 1918)

(2006). Uma criança é espancada: uma contribuição ao estudo da origem das perversões sexuais. Em Edição standard brasileira das obras psicológicas completas de Sigmund Freud. Vol. XVII. Rio de Janeiro: Imago. (Original publicado em 1919)

(2006). A cabeça da Medusa. Em Edição standard brasileira das obras psicológicas completas de Sigmund Freud. Vol. 18. Rio de Janeiro: Imago. (Original publicado em 1922)

(2007). O Eu e o Id. Em Obras psicológicas de Sigmund Freud: Escritos sobre a psicologia do inconsciente. Vol. 3. Rio de Janeiro: Imago. (Original publicado em 1923)

. (2007). O problema econômico do masoquismo. Em Obras psicológicas de Sigmund Freud: Escritos sobre a psicologia do inconsciente. Vol. 3. Rio de Janeiro: Imago. (Original publicado em 1924)

. (2007). Uma nota sobre o bloco mágico. Em Obras psicológicas de Sigmund Freud: Escritos sobre a psicologia do inconsciente. Vol. 3. Rio de Janeiro: Imago. (Original publicado em 1925)

(2007). A negativa. Em Obras psicológicas de Sigmund Freud: Escritos sobre a psicologia do inconsciente. Vol. 3. Rio de Janeiro: Imago. (Original publicado em 1925)

. (2007). Análise terminável e interminável. Em Edição standard brasileira das obras psicológicas completas de Sigmund Freud. Vol. 23. Rio de Janeiro: Imago. (Original publicado em 1937)

(2006). Construções em análise. Em Edição standard brasileira das obras psicológicas completas de Sigmund Freud. Vol. 23. Rio de Janeiro: Imago. (Original publicado em 1937)

. (2006). Esboços de psicanálise. Em Edição standard brasileira das obras psicológicas completas de Sigmund Freud. Vol. 23. Rio de Janeiro: Imago. (Original publicado em 1940 [1938]) 
(2014). Compendio de psicanálise. Em Obras incompletas de Sigmund Freud. Edição bilíngue. Belo Horizonte/ São Paulo: Autêntica. (Original publicado em 1940 [1938])

. (2007). A cisão do eu no processo de defesa. Em Obras psicológicas de Sigmund Freud: Escritos sobre a psicologia do inconsciente. Vol. 3. Rio de Janeiro: Imago. (Original publicado em 1940 [1938])

(2014). A cisão do Eu no processo de defesa. Em Obras incompletas de Sigmund Freud. Belo Horizonte/ São Paulo: Autêntica. (Original publicado em 1940 [1938])

Gabbi Jr., O. F. (2003). Notas a projeto de uma psicologia: as origens utilitaristas da psicanálise. Rio de Janeiro: Imago.

Hesíodo (2013). Teogonia. (Trad. Christian Werner). São Paulo: Hedra. (Original publicado em séculos VIII e VII a. C.)

Kaufmann, P. (Org.). (1996). Dicionário enciclopédico de psicanálise: o legado de Freud e Lacan. Rio de Janeiro: Jorge Zahar.

Kierkegaard, S. (2009). A repetição. Lisboa: Relógio d'água. (Original publicado em 1843)

Kojève, A. (2002). Introdução à leitura de Hegel. Rio de Janeiro: Contraponto/Eduerj. (Original publicado em 1947)

Lacan, J. (1998). O estádio do espelho como formador da função do eu. Em Escritos. Rio de Janeiro: Jorge Zahar. (Original publicado em 1949/1966)

(1998). O tempo lógico e a asserção da certeza antecipada Em Escritos. Rio de Janeiro: Jorge Zahar. (Original publicado em 1945/1966)

. (1998). Função e campo da fala e da linguagem em psicanálise. Em Escritos. Rio de Janeiro: Jorge Zahar. (Original publicado em 1953)

. (2010). O seminário livro 2 - O eu na teoria de Freud e na técnica da psicanálise. Rio de Janeiro: Jorge Zahar. (Original publicado em 1954-1955)

(2002). O seminário livro 3 - As psicoses. Rio de Janeiro: Jorge Zahar. (Original publicado em 1955-1956)

(1995). O seminário livro 4 - A relação de objeto. Rio de Janeiro: Jorge Zahar. (Original publicado em 1956-1957)

. (2005). O seminário livro 10 - A angústia. Rio de Janeiro: Jorge Zahar. (Original publicado em 1962-1963)

(2008). O seminário livro 11 - Os quatro conceitos fundamentais da psicanálise. Rio de Janeiro: Jorge Zahar. (Original publicado em 1964) 
(2003). A lógica da fantasia - resumo do seminário de 1966-67. Em Outros escritos. Rio de Janeiro: Jorge Zahar. (Original publicado em 1966-1967)

. O seminário 15 - $O$ ato psicanalítico. (Versão extraoficial do seminário proferido em 1967-1968)

(2007). O seminário livrol7 - O avesso da psicanálise. Rio de Janeiro: Jorge Zahar. (Original publicado em 1969-1970)

(2003). Radiofonia. Em Outros escritos. Rio de Janeiro: Jorge Zahar. (Original publicado em 1970)

(2008). O seminário livro 20 - Mais, ainda. Rio de Janeiro: Jorge Zahar. (Original publicado em 1972-1973)

Laplanche, J. e Pontalis, J-B. (2001). Vocabulário da psicanálise. São Paulo: Martins Fontes.

Leite, N. (1994). Psicanálise e análise do discurso: o acontecimento na estrutura. Rio de Janeiro: Campo Matêmico.

Maesso, M. C. (2013). O diagnóstico, seu avesso e a posição do psicanalista. Curitiba: Juruá.

Perini, M. A. (2010). Gramática do português brasileiro. São Paulo: Parábola.

Porge, E. (1998). Psicanálise e tempo: o tempo lógico de Lacan. Rio de Janeiro: Companhia de Freud.

Roudinesco, E. e Plon, M. (1998). Dicionário de psicanálise. Rio de Janeiro: Jorge Zahar.

Sófocles (2010). Édipo rei. (Trad. Paulo Neves). Porto Alegre: L\&PM. (Original publicado em 496 a.C.- 407 a. C.)

Soler, C. (2013). A repetição na experiência analítica. São Paulo: Escuta.

Torres, R. S. (2010). Dimensões do ato em psicanálise. São Paulo: Annablume. 